\title{
A Constitutional Right to Preschool?
}

\author{
James E. Ryan $\dagger$
}

Access to publicly financed preschool looms as the next big issue in education law and policy. State programs, which now exist in forty states and the District of Columbia, have mushroomed over the last decade, complementing the well-established federal Head Start program. Currently, about $25 \%$ of all three- and four-year-olds attend publicly funded preschool, ${ }^{1}$ and a bit more than $25 \%$ attend private preschool. ${ }^{2}$ This leaves slightly less than half of this age cohort out of preschool altogether. Those left out number in the millions, and they tend to be from relatively poor and less-educated families. ${ }^{3}$

Public support for increasing access to preschool is substantial and diverse. Groups across the political spectrum are championing the cause, including teachers' unions, business associations, anticrime groups, philanthropie foundations, and even analysts from the Federal Reserve Bank. ${ }^{4}$

Copyright (C) 2006 California Law Review, Inc. California Law Review, Inc. (CLR) is a California nonprofit corporation. CLR and the authors are solely responsible for the content of their publications.

$\dagger \quad$ William L. Matheson and Robert M. Morgenthau Distinguished Professor, University of Virginia School of Law. Thanks to Barry Cushman, James Forman, Michael Heise, John Jeffries, Mike Klarman, Melanie Leslie, Daryl Levinson, Goodwin Liu, Liz Magill, Jeff Rachlinski, Aaron Saiger, Tom Saunders, Peter Schuck, Scott Shapiro, Ted White, and participants at faculty workshops at Cardozo and Comell Law Schools for helpful conversations and comments, and to Lisa Chadderdon, Greg Henning, Monika Moore, and Megan Strackbein for excellent research assistance. Special thanks to the research librarians at the University of Virginia Law School for expert and cheerful assistance.

1. Nat'l Ctr. for Educ. Stat., U.S. Dep't of Educ., The Condition of Education 2002, at 43 (2002), available at http://nces.ed.gov/pubs2002/2002025.pdf [hereinafter NCES, CoNDITION OF EDUCATION1 (indicating that $56 \%$ of children ages three to five who were not in kindergarten were in a preschool program in 2001, the most recent year for which enrollment figures are available).

2. W. Steven Barnett et al., The State of Preschool: 2003 State Preschool Yearbook 8 (2003) [hereinafter Barnett, State of Preschool); Nat'l Ctr. for Educ. Stat., U.S. Dep't of Educ., Digest of Education Statistics 2002, at 59 tbl.43 (2003), available at http://nces.ed.gov/pubs2003/2003060b.pdf [hereinafter NCES, DigEST OF EDUCATION STATISTICs].

3. NCES, CONDITION of EduCATION, supra note 1, at 1-2; see also COMM. FOR ECON. DEv., Preschool for All: Investing in a Productive and Just Society 17 (2002) [hereinafter CED, PResChOOL FOR ALL] ("Children of higher-income and better-educated parents are the most likely to have the advantage of participating in early education programs."); Prekindergarten, Educ. WK. ON THE WEB, Jan. 10, 2004, www.edweek.org/sreports/qc02/templates/article/ cfm?slug=17exec.h21 [hereinafter EducATION WEEK] ("Families with low incomes, particularly the working poor, have the least access to high-quality, early-childhood services."); Lisa N. Staresina, Prekindergarden, EDUC. WK. ON THE WEB, Jan. 10, 2004, http://secure.edweek.org/context/topics/ issuespage. $\mathrm{cfm}$ ? id=114.

4. See infra notes 211 through 232 and accompanying text. 
Polls, moreover, consistently reveal widespread support for expanding access to preschool. ${ }^{5}$

Several factors have combined to spark this recent embrace of preschool. Advances in neuroscience have made it clear that the first few years of life are crucial for cognitive development and that early experiences can influence the emerging architecture of the brain. ${ }^{6}$ The media have devoted a great deal of attention to these findings, stimulating public interest and creating the impression that early childhood offers a rare opportunity to enrich a child's development. Although much of the research has focused on the first three years of life, when the great majority of physical brain development occurs, it has nonetheless helped fuel a drive to begin education at an earlier age. ${ }^{7}$

Social science evidence, in turn, suggests that preschool produces definite and substantial gains in learning and development, at least over the short-run. Some programs, though not all, have also produced lasting academic gains, reduced grade retention and placement in special education, increased graduation rates, and decreased crime and delinquency rates. ${ }^{8}$ The social science evidence about preschool is not conclusive on all counts. But unlike the social science evidence about other educational reforms, such as desegregation or school funding, most of the evidence about preschool points in one direction and is not contradictory or intensely contested. ${ }^{9}$ In addition, researchers have been savvy in focusing their research and communicating their findings. A number of researchers, for example, have made rough calculations regarding the costs and benefits of preschool, concluding that in most cases preschool will more than pay for itself. ${ }^{10}$ These calculations have proven politically salient; those advocating greater access to preschool often refer to the cost savings that such programs can generate. ${ }^{11}$

5. See infra note 211 and accompanying text.

6. See Janet Currie, The Brookings Institution, Early Childhood Intervention Programs: What Do WE KNOW? 8-9 (2000), available at http://www.brookings.edu/es/ research/projects/cr/doc/currie2000040I.pdf (discussing reasearch on early brain development); Carey Goldberg, The Promise of Preschool, Boston Globe, Mar. 23, 2004, at Cl (quoting Dr. Jack Shonkoff, editor of a 2000 National Academy of Sciences report on early childhood development).

7. LyNn A. Karoly, RAND, Investing IN our ChILdRen xi (1998) [hereinafter RAND StUdY].

8. For a detailed discussion of the social science evidence, see infra Part I.A.

9. For a discussion of the social science evidence regarding desegregation and school finance reform, see James E. Ryan, Schools, Race, and Money, 109 YALE L.J. 249, 284-307 (1999).

10. See infra Part I.A and Part I.B.4.

11. See, e.g., Michael D. Shear, Kaine Backs Offering Free Preschool for 4-Year-Olds, WASH. Post, Aug. 10, 2005, at B1 (noting that Democratic gubernatorial candidate Timothy M. Kaine vowed to make preschool available to every four-year-old Virginian, pointing out that the costs of such a program would be offset by money saved on remedial education); Mike Vogel, Lieutenant Governor Urges Expansion of Prekindergarten, Buffalo News, Sept. 11, 1996, at 4B (quoting Lieutenant Governor Betsy McCaughey Ross: "prekindergarten is the best investment New York can make."). 
A greater need for childcare among working parents has also helped motivate legislatures to provide funding for preschool. As of 2000 , over $70 \%$ of women with children between the ages of three and five were in the workforce. $^{12}$ This rate of employment, which represents a dramatic rise over the last fifty years, has increased demand for quality childcare and early education.

Last, the beneficiaries are a sympathetic and appealing group. One can hardly blame these young children for their own circumstances. They are as innocent and untainted as any group can be. Assisting children at this stage in their lives, to get them "on the right path," is an inherently attractive idea, as proven nearly a century ago by the successful arguments made on behalf of expanding access to kindergarten. ${ }^{13}$ Just as importantly, most of the programs are as young and innocent as the children they serve. These programs are free from the taint of bureaucratic inefficiency or failure that hangs over a number of existing school systems, especially in urban areas. ${ }^{14}$ Politicians and advocates can thus still be optimistic about the possibility of creating widely available, high-quality preschools, in a way they cannot be about creating, say, high-quality, large, urban high schools.

Until now, most advocates for expanding access to preschool have confined their efforts to the legislative and political spheres. It seems inevitable, however, that courts will be asked to consider whether children have a right to publicly funded preschool. Alexis De Tocqueville's observation, that most political issues in this country eventually become legal questions, ${ }^{15}$ has become trite, but only by virtue of its consistent confirmation. Preschool will likely be no exception to this pattern.

12. CED, Preschool for All, at 7.

13. For good histories of the kindergarten movement, see Barbara BeatTy, Preschool Education in america: The Culture of Young Children From the Colonial Era to the Present 52-132 (1995); Elizabeth Dale Ross, The Kindergarten Crusade: The Establishment of Preschool Education in the United States (1976); Michael S. Shapiro, Child's Garden: The Kindergarten Movement from Froebel to Dewey (1983); Ann Taylor Allen, "Let us Live With Our Children": Kindergarten Movements in Germany and the Unities States, 1840-1914, 28 Hist, of EDuc. Q. 23 (1988).

14. Bureaucratic waste and inefficiency are often cited by states as reasons not to increase funding for K-12 education. See, e.g., Abbott v. Burke, 575 A.2d 359, 363 (N.J. 1990).

15. Alexis De Tocqueville, Democracy in America 280 (Henty Reeve trans., 1959) (18351840). 
In fact, several state courts have already entered the fray. ${ }^{16}$ The Supreme Court of New Jersey recognized a right to preschool for students living in poor, urban districts. ${ }^{17}$ By contrast, the supreme courts of Massachusetts, North Carolina, and Arkansas declined to recognize a right to preschool, all overturning trial court decisions that had done so. ${ }^{18}$ This does not represent a juggernaut in favor of a right to preschool, obviously, but it does seem to herald the start of a trend. In the short space of five years, four courts-counting the trial courts whose decisions were reversed-were willing to recognize a right to preschool.

The courts that have recognized a right to preschool have relied on the education elauses that exist in their respective state constitutions, and they have ordered access to preschool in the context of school funding lawsuits. All state constitutions guarantee children a right to education, and roughly twenty state supreme courts have interpreted these provisions to guarantee students the right to an equal or adequate education. ${ }^{19}$ It stands to reason that other state courts will at least contemplate following the lead of those that have already recognized a right to preschool.

Given these political and legal developments, it seems an appropriate time to consider whether access to preschool ought to be expanded and, if so, whether state courts should play a role. As for the first issue, the case for expanding access to preschool is very strong, at least to ensure that all poor four-year-olds can attend a publicly funded program. As researchers have uniformly demonstrated, the benefits of preschool, for this group in particular, seem easily to outweigh the costs. ${ }^{20}$

The second issue, regarding the court's role, is somewhat more complicated. My overall conclusion, in brief, is that pursuing litigation as part of a larger political strategy is worthwhile. It is quite fashionable these days, in academic circles, to discount, if not completely disparage, the

16. Advocates have not yet filed federal claims, and probably will not do so in the near future. It is possible to articulate a plausible federal claim, based on the Equal Protection Clause. The claim would combine dicta from San Antonio v. Rodriguez, 411 U.S. 1, 25 n.60, 37 (1973), in which the Court suggested that children may have a right of access to free, public education, with an expansive reading of Plyler v. Doe, 457 U.S. 202 (1982), where the Court struck down a law that effectively barred the children of illegal immigrants from receiving a free, public education. The basic argument would be that the Equal Protection Clause prohibits states from providing preschool to some disadvantaged children while denying access to others. Whatever its merits, the odds of such a claim succeeding seem slim, especially given the current tenor of most federal courts of appeal, as well as the ideological bent of the current U.S. Supreme Court. For this reason, this Article is confined to state claims.

17. Abbott v. Burke, 748 A.2d 82 (N.J. 2000); Abbott v. Burke, 693 A.2d 417, 436 (N.J. 1997).

18. Lake View Sch. Dist. No. 25 v. Huckabee, 91 S.W.3d 472, 500-02 (Ark. 2002); Hancock v. Comm'r of Educ., 822 N.E.2d 1134, 1156-57 (Mass. 2005); Hoke County Bd. of Educ. v. State, 599 S.E.2d 365, 393-94 (N.C. 2004).

19. Molly S. McUsic, The Future of Brown v. Board of Education: Economic Integration of Public Schools, 117 HaRv. L. REv. 1334, 1345-46 \& n. 72 (2004).

20. See infra notes 96 through 117 and accompanying text. 
usefulness of litigation to achieve social change. ${ }^{21} I$ think this new conventional wisdom is wrong in this context. In my view, the conditions are ripe for successful and effective litigation in state courts.

The legal claim, to begin, is quite strong, and courts would be justified in concluding that their respective state constitutions protect a right of access to preschool. As I explain in detail below, state education clauses, and cases interpreting them in the context of funding suits, provide a solid basis upon which to rest a claim to preschool. Litigants in states whose courts have already recognized a constitutional right to adequate or equal educational opportunities have particularly strong arguments, as there are many reasons why preschool ought to be included within any definition of an adequate or equal education.

There is good reason to believe, moreover, that successful litigation will have a real impact. Many state legislatures seem poised to act and are rhetorically committed to expanding access to preschool. But thus far they have failed to follow through, most likely because of the costs involved and the specter of having to raise taxes to fund preschool. ${ }^{22}$ This gives rise to an anomaly: even though polls suggest that a majority of voters would support increased and even universal access to preschool, legislatures appear worried about the steps necessary to reach that end point.

Under these circumstances, courts can play an effective and productive role, and one that arguably enhances rather than impedes the political process. By recognizing a right to preschool, courts could provide cover for risk-averse legislators who would like to increase access but fear repercussions from raising taxes or cutting other programs. This is precisely how some successful school finance cases have played out in the legislatures. ${ }^{23}$

In addition, given the widespread support for expanding access to preschool, there is little risk that a court ruling would create a significant backlash akin to those created by rulings on such socially divisive issues as

21. See, e.g., Enwin Chemerinsky, Losing Faith: America Without Judicial Review?, 98 Mich. L. REv. 1416, 1416 (2000) ("In the last decade, it has become increasingly trendy to question whether the Supreme Court and constitutional judicial review really can make a difference."). Scholars have asked similar questions about state courts, particularly about their role in school finance litigation. See, e.g., Michael J. Heise, Equal Educational Opportunity, Hollow Victories, and the Demise of School Finance Equity Theory: An Empirical Perspective and Alternative Explanation, 32 GA. L. REv. 543, 585-628 (1998) (reviewing existing literature and conducting original empirical analysis).

22. See Linda Jacobson, Report Finds State Preschool Funds Fall Short of Rhetoric, Educ. WK., Apr. 21, 2004, at 20 ("An analysis of govemors' budget proposals for the upcoming fiscal year shows that even though many of them talk about a need to improve early-childhood programs, most have not recommended higher spending for school-readiness services.").

23. See Michael Paris, Legal Mobilization and the Politics of Reform: Lessons from School Finance Litigation in Kentucky, 1984-1995, 26 LAW \& Soc. 1NQUIRY 631, 633-34 (2001) (arguing that the Kentucky Supreme Court's school finance decision 'provided 'cover' for elected officials to endorse tax increases."). 
abortion and gay rights. ${ }^{24}$ At the same time, the support of teachers' unions, the business community, and preschool providers would create a powerful, market-based constituency to support and implement a court-created right to preschool. ${ }^{25}$ Note, finally, that litigation need not be uniformly successful in order to promote widespread reform. Given the dynamics of interstate competition for businesses and residents and the importance of education to that competition, ${ }^{26}$ court victories in several states could very well spur legislatures in other states to match their neighbors in expanding access to preschool.

This Article consists of three Parts. Part I sets out the basic facts about preschool, first describing the current landscape of public and private preschool programs and then turning to social science evidence regarding their effects. Part II addresses potential legal claims, examining existing doctrine and arguing that there is a strong basis in state constitutional law for recognizing a right of access to preschool, at least for disadvantaged students. Part III explaims why court involvement here would likely be productive and effective. I conclude with some brief observations about the ongoing debate regarding the role of courts in fostering social change.

\section{I}

\section{The Facts About Preschool}

\section{A. Access, Cost, and Quality}

Until recently, the federal government played the leading role in providing public access to preschool, through the well-known Head Start program. But that is beginning to change. Forty states and the District of Columbia currently sponsor preschool programs, up from only ten in $1980 .{ }^{27}$ State spending has increased dramatically, growing from $\$ 190$ million in 1988 to $\$ 2.4$ billion in 2001-02. ${ }^{28}$ Enrollment in state programs now almost matches enrollment in federal Head Start programs. ${ }^{29}$

24. See Michael J. Klarman, Brown and Lawrence (and Goodridge) (Univ. of Va. Pub. Law and Legal Theory Working Paper Series, Working Paper No. 16, 2005), available at http://law.bepress.com/ uvalwps/uva_publiclaw/art16/.

25. See Gerald Rosenberg, The Hollow Hope: Can Courts Bring about Social CHANGE? 33 (1991) (suggesting that court-ordered reform is likely to work when supported by market forces).

26. See James E. Ryan, The Perverse Incentives of the No Child Left Behind Act, 79 N.Y.U. L. REv. 932, 949-51 (2004) [hereinafter Ryan, Peverse Incentives] (reviewing litcrature on interstate competition and incentives among state officials to use schools as a means of attracting businesses and residents).

27. Barnett, State of Preschool, supra note 2, at 140.

28. Id. at 17; EDUC. WEEK, supra note 3, at 3.

29. Anne W. Mitchell, Education for All Young Children: The Role of the States and Federal Government in Promoting Prekindergarten and Kindergarten 5 (Apr. 2001) (Found. for Child Dev., Working Paper), http://www.fcd-us.org/uploaddocs/ecpc\%20mitchell.pdf [hereinafter Mitchell, Education for All Young Children]. As Mitchell describes, the federal government also funds preschool 
Despite this growth, most states are still a long way from offering universal access to preschool. Like the federal Head Start program, most state programs limit eligibility to poor children, and even then serve only a fraction of this group. ${ }^{30}$ There are some exceptions. Georgia offers universal access to preschool, and Oklahoma comes close, offering districts funding if they choose to provide preschool. ${ }^{31}$ New York and West Virginia have passed legislation that calls for implementing universal preschool. ${ }^{32}$ And thanks to a ballot initiative, four-year-olds in Florida have become the first children in the nation to be granted an explicit state constitutional right to a "high-quality" preschool education. ${ }^{33}$

The universe of publicly funded preschool programs is complicated and chaotic. There is nothing close to a system of preschools, in any state, that is remotely comparable to the system of $\mathrm{K}-12$ public schools. Unlike $\mathrm{K}-12$ education, moreover, the federal government pays the lion's share of funds spent on preschool, spending roughly three times the amount spent by all states combined. ${ }^{34}$ Also unlike public K-12 education, "public" preschool programs are more likely to be offered outside of the public schools than within them. ${ }^{35}$ Most publicly funded preschool programs rely heavily on private providers, including for-profit, non-profit, and religious organizations. $^{36}$

In terms of funding per pupil, states vary a great deal. On average, states spend much less per child on preschool than they do on K-12 education. In 2001-02, states spent an average of $\$ 3,455$ on each preschooler, compared with an average of $\$ 8,733$ spent per pupil in $\mathrm{K}-12$ education. ${ }^{37}$ States also generally spend much less per child than the federal government does through Head Start, which provides close to $\$ 7,000$ per pupil. ${ }^{38}$ Although the Head Start figure is somewhat inflated because of the additional programs provided to children, such as health and nutritional

through other spending programs, including Title 1, but Head Start is by far the largest federally funded preschool program.

30. Barnett, State of Preschool, supra note 2, at 22-24; CED, Preschool For All, supra note 3 , at 12 .

31. See Ga. Dep't of Early Care and learning, Bright from the Start: 2005 -2006 School Year Pre-K Providers' Operating Guidel.ines 1-2, http://www.decal.state.ga.us/ Documents/PreK/guidelines2005.pdf; William T. Gormley Jr. \& Deborah Phillips, The Effects of Universal Pre-K in Oklahoma: Research Highlights and Policy Implications, 33 PoL'Y STUD. J. 65 (2005).

32. N.Y. Educ. Law § 3602-e (McKinney 2005); W. VA. CodE ANN. § 18-5-44 (Lexis Nexis 2005); Barnett, State of Preschool, supra note 2, at 9.

33. FLA. CONST. art. IX, § 1 (b).

34. Lynn Olson, Starting Early, Educ. WK., Jan. 10, 2002, at 10.

35. Mitchell, Education for All Young Children, supra note 29, at 2.

36. One of the more interesting facts about publicly funded preschool programs is that they have operated akin to voucher programs. They have done so, moreover, under the radar screen of voucher opponents and proponents, who have largely iguored the universe of publicly funded preschools.

37. Barnett, State of Preschool, supra note 2, at 19, 38-41.

38. Id. 
services, it is nonetheless telling that only two states-New Jersey and Oregon-spend more per preschool child. ${ }^{39}$

As resources differ among states, so too does the quality of the programs provided. The National Institute for Early Education Research recently completed a study of all state preschool programs, which attempted to assess their quality. The study examined ten proxies for quality, including curriculum standards, teacher degree requirements, maximum class size, and teacher-child ratios. States varied tremendously in terms of how many criteria were met, with some state programs meeting nine of the ten criteria and others meeting only two. ${ }^{40}$ As one would expect, variation in quality produces variations in effects. The social science evidence, discussed presently, suggests that only fairly high-quality preschools have lasting effects on students. It also suggests, however, that creating such preschools would be financially plausible and, indeed, a wise investment.

\section{B. Social Science Research}

Studies of the effects of preschool and other early childhood interventions are legion. Head Start alone has been the subject of over 600 separate studies, ${ }^{41}$ and myriad studies exist of other preschool programs, both public and private. Not all of the studies are reliable ones, and much of the research suffers from methodological weaknesses, including the lack of randomized samples. That said, there is a consensus in the social science literature on several important points.

First, there is typically a wide gap in school readiness between poor and more affluent children when they enter kindergarten. ${ }^{42}$ When children begin school behind, they tend to fall further behind. ${ }^{43}$ This is an increasingly important problem given the rise of test-based accountability, implemented through the No Child Left Behind Act and state accountability systems, which pressures schools to ensure that all children are performing at grade level. ${ }^{44}$ This is obviously harder to do when a substantial number of children begin school behind where they ought to be. The gap before kindergarten is thus obvious, and the need to do something about it is increasingly acute.

\footnotetext{
39. Id.

40. Id. at 31-35.

41. Gen. Accounting Office, Head Start: Research Provides Little Information on Impact of Current Program 2 (1997) [hereinafter GaO, Head Start Research].

42. Valerie E. Lee \& David T. Burkam, Inequality at the Starting Gate (2002).

43. See generally NAT'L Res. Council and Inst. OF Med., From Neurons to Neighborhoods: The Science of Early Childhood Development 386 (Jack P. Shonkoff \& Deborah A. Philips eds., 2000) [hereinafter From NEURons to NeIGHBORHoODs].

44. See Ryan, Peverse Incentives, supra note 26, at 961-80 (discussing the No Child Left Behind Act); Vincent Ferrandino, Preschool Makes Perfect-\$ense, Nat'L Ass'N OF Elementary Sch. PrinCIPAls, Apr. 14, 2004, http://www.naesp.org/ContentLoad.do?contentId=1235 (arguing that the demands of the NCLBA require better preparation of presehoolers).
} 
Second, studies suggest that high-quality preschools for disadvantaged children help close the gap in school readiness. In addition, researchers agree that preschool programs can have long-term, positive effects on academic achievement. Preschool programs can also significantly reduce grade retention rates and demand for special cducation services, increase graduation rates and employment prospects, and decrease crime rates. As a consequence, high-quality preschool programs can generate savings to the government that exceed the costs of the program..$^{45}$

Not all preschool programs, of course, provide all of these benefits. As one would expect, the more intensive (and therefore expensive) the program, the more likely it is to generate benefits. ${ }^{46}$ This raises the recurring "scaling up" question-namely, whether model programs with demonstrable benefits can be replicated on a large scale. ${ }^{47}$ Although no definitive answer yet exists, encouraging evidence surfaced in a recent study of a public preschool program in Chicago, the Chicago Child-Parent Centers (CPCs). Funded primarily by the federal government through Title $\mathrm{I}$, this program has generated significant and lasting benefits for participants and the public, including lower rates of grade retention and placement in special education, higher rates of graduation, and lower rates of juvenile arrest. ${ }^{48}$ Early studies of the nascent public preschool programs in Oklahoma and Georgia have also produced promising, though obviously less conclusive, results. ${ }^{49}$

To make sense of this large body of research, it is best to divide it into two general categories. The first consists of studies of model programs created and implemented for the purpose of examining the impact of early childhood interventions. The second consists of studies of large scale programs, like Head Start and CPCs, which are more widely available and were not created as research tools. Within each category, it is useful to consider both short- and long-term effects. After reviewing this evidence, I

45. For a thorough discussion of the points raised in this paragraph, see infra notes 96 through 117 and accompanying text.

46. W. Steven Barnett, Early Childhood Education, in School Reform Proposals: The RESEARCH EvidENCE 8 n.72 (Alex Molnar ed., 2002) [hereinafter Barnett, Early Childhood Education].

47. See, e.g., Martin Woodhead, When Psychology Informs Public Policy: The Case of Early Childhood Intervention, 43 AM. Psychologist 443, 443 (1988) (raising doubts about ability to replicate findings from model programs in large-scale public programs); Goldberg, supra note 6 (quoting David Blau, economist at University of North Carolina, who doubts that model programs can "be duplicated in a broad public system").

48. Arthur J. Reynolds et al, Long-Term Effects of an Early Childhood Intervention on Educational Achievement and Juvenile Arrest: A I5-Year Follow-up of Low-Income Children in Public Schools, 285 J. OF AM. MED. Ass'N. 2339, 2339 (2001) [hereinafter Reynolds et al., Long-Term Effects].

49. Goldberg, supra note 6; Clive R. Belfield, Early Childhood Education: How Important are the Cost-Savings to the School System? 5 (Feb. 2004) (unpublished report prepared for the Center for Early Care and Edueation), available at http:/www.winningbeginningny.org/databank/documents/ belfield_report_000.pdf. 
address the question of targeting (that is, whether preschool benefits certain groups of children more than others) and then turn to existing research regarding the costs and benefits of various preschool programs.

\section{Model Programs}

The two most intensively studied preschool programs are the High/Scope Perry Preschool Project and the Abecedarian Project. In the research and policy world, these well-known programs simultaneously inspire the most optimism and the most skepticism-optimism because the benefits are clear, strong, and long lasting; skepticism because it seems at first blush that thcse model programs cannot be replicated on a large scale.

Perhaps the most famous of all model preschool programs is the Perry Preschool Project in Ypsilanti, Michigan. Its fame rests on both the research design and the findings. The participants consisted of 123 disadvantaged, low-IQ African-American children, who were randomly assigned to either the preschool program or a control group. Children enrolled over the course of five years, between 1962 and 1967; forty-five entered preschool at age three and attended for two years, and thirtecn entered at age four and attended for one year. They attended preschool five days a week, between October and May, for two and a half hours each day. The teacher-student ratio was one to six, and all of the teachers were certified and trained in early childhood development. Teachers also visited the children's homes once each week for ninety minutes. ${ }^{50}$

The study tracked program participants annually through age eleven and then again at ages fourteen, fifteen, nineteen, twenty-seven, and forty. Attrition was very low, even through the most recent study. ${ }^{51}$ The randomized assignment, long-follow up, and low attrition rates make this one of the best-designed studies ever conducted, and one of the most reliable, although the relatively small sample sizes are nonetheless a drawback.

The study collected information about a broad range of outcomes, and produced impressive findings. Participants experienced an initial boost in IQ, but this faded by age eight. Boosting IQ test scores, however, is not the only way to increase academic achievement, as demonstratcd by this and other studies. Achievement scores remained significantly higher for participants than for those in the control group, through age fourteen. Participants also had better grades throughout their school years, higher graduation rates, and lower rates of grade retention and special education placement. By age twenty-seven, moreover, they had significantly lower rates of current or past welfare dependency, and lower criminal activity,

50. This description comes from RAND STUDY, supra note 7, at 34-36.

51. Id. at 35; Lawrence J. Schweinhart, Lifetime Effects: The High/Scope Perry Preschool Study Through Age 401 (2002), http://www.highscope.org/Research/PerryProject/ PerryAge40SumWeb.pdf. 
both in terms of incidence and severity. Employment rates and earnings for program participants were also higher. ${ }^{52}$ The most recent study found that participants at age forty had higher employment rates, earned more income, and had committed fewer crimes than the control group. ${ }^{53}$ Several researchers have monetized these benefits and have concluded that the program more than paid for itself in terms of savings to the government. ${ }^{54}$ Indeed, the most recent estimates indicate that the economic return to the public has been nearly \$I3 for every \$I originally invested in the program, due to crime, education, and welfare savings, as well as increased tax revenue due to higher earnings. ${ }^{55}$

The Abecedarian Project began in 1972 under the auspices of the Child Development Center at the University of North Carolina. Like the Perry Preschool Project, researchers focused on disadvantaged children and randomly assigned them to a preschool program or a control group. Unlike the Perry Preschool Project, children began participating in the Abecedarian program shortly after birth. Participants enrolled in day care at six weeks of age and received services for eight hours each day, five days a week, for fifty weeks per year until they entered kindergarten. The teacher-student ratio was one to three for infants and then one to six for three- and four-year- olds. At school entry, the researchers again randomly assigned the children into two groups. One received no intervention, and the other received assistance from a resource teacher who worked with the children and their families to provide additional instruction and to act as a liaison between home and school. ${ }^{56}$

One hundred and eleven children enrolled in the program between 1972 and 1975. They were followed until age twenty-one. Like the Perry Preschool Project, findings from this study were impressive. Participants again experienced an initial IQ boost, which continued to be significantly higher through age twelve and by age fifteen was favorable but not statistically significant. Also through age fifteen, the children who participated in preschool had higher achievement scores, especially in reading, and lower rates of grade retention and special education placement, regardless of whether they received further assistance once they entered school. ${ }^{57}$ At age twenty-one, all but seven of the original one hundred and eleven children

52. Id. at 36-37; see also Currie, supra note 6, at 12; LAWREnCE J. SchWEINharT ET AL., Significant Benefits: The High/Scope Perry Preschool Study Through Age 27 (1993).

53. Schweinhart, The High/Scope Perry Preschool Study Through Age 40, supra note 51 , at $1-3$.

54. See infra Part 1.B.4.

55. Schweinhart, The HighlScope Perry Preschool Study Through Age 4o, supra note 51 , at 3 .

56. This description comes from RAND STUDY, supra note 7, at 51-52, and Currie, supra note 6, at $11-12$.

57. These findings are reported in RAND STUDY, supra note 7, at 50-51, and Currie, supra note 6, at 11-12. 
were assessed. The participants had higher average test scores, and were twice as likely to be in post-secondary education or to have attended a four-year college. Employment rates for participants were also higher, but the difference was not statistically significant. ${ }^{58}$

Findings from studies of other model programs are generally consistent with those of the Perry and Abecedarian Projects, though not all programs have had as strong an impact, and none of the other studies has followed participants for as long a time period. Nonetheless, the studies are instructive, and the best place to begin is with Professor Barnett's overview.

W. Steven Barnett, a professor at Rutgers University Center for Early Education and the Director of the National Institute for Early Education Research, recently reviewed the findings from fifteen studies of model preschool programs. ${ }^{59}$ The studies examined the impact of the programs on IQ and achievement scores, grade retention, special education placement, and high school graduation. Barnett concluded that there was "overwhelming evidence that [preschool] can produee sizeable improvements in school success." ${ }^{600}$

All of the model programs studied found initial positive effects on IQ, which faded shortly after kindergarten. ${ }^{61}$ Achievement gains, by contrast, tended to be longer lasting and in some studies observable into middle and high school. Similarly, the studies showed consistently strong effects on grade retention and special education. All but one of the fifteen studies kept track of grade retention and special education placement, and all fourteen found lower rates for program participants. ${ }^{62}$ On average, $20 \%$ fewer participants were placed in special education, and $15 \%$ fewer had to repeat a grade. ${ }^{63}$ Evidence regarding high school graduation rates is sparser but equally consistent. Three of the model program studies assessed effects on graduation, and all three found that participation in preschool increased the chances of high school graduation. ${ }^{64}$

Other researchers have reached similar conclusions. A research team from RAND, for example, reviewed nine model programs and concluded "that carefully targeted early childhood interventions can yield measurable benefits in the short run and that some benefits persist long after the program has ended." 65 Janet Currie, an economist at UCLA, reviewed studies

58. These findings are reported in Currie, supra note 6 , at 11-12, and ThE CARolina Abecedarian Project, Early Learning, Later Success: The Abecedarian Study (2003), http://www.fpg.unc.edu/abc/summary.cfm.

59. Barnett, Early Childhood Education, supra note 46.

60. Reynolds et al., Long-Term Effects, supra note 48, at 48.

61. Id. at 6 n. 57

62. Id.

63. Barnett, Early Childhood Education, supra note 46 , at 7 n.61

64. Reynolds et al, Long-Term Effects, supra note 48, at 41 .

65. RAND STUDY, supra note 7 , at 61 . 
of model and large-scale programs. She concluded that "model early intervention programs can have positive long-term effects on children," including increased achievement, lower grade repetition, decreased rates of special education placement, and higher graduation rates. ${ }^{66}$ Other social scientists agree with these overall conclusions, even those who are skeptical that model programs can be replicated on a large scale. ${ }^{67}$

Importantly, state trial courts have also concluded that high-quality preschools can produce long-Iasting benefits to participants. In Hancock $v$. Driscoll, for example, school finance plaintiffs in Massachusetts requested that the trial court order publicly funded preschool as one part of an "adequacy" remedy. After considering the social science evidence presented by both sides, Judge Botsford concluded:

The uncontradicted trial evidence reveals that in the field of early childhood education, there are a great number of research-based and experimental studies demonstrating the benefits of high quality programming for young children at risk, benefits that in the shorter term include improving the children's school readiness, socialization skills, and school performance. High quality early child education has longer-term advantages as well, including increased high school graduation rates, increased college attendance rates, better employment, and less involvement with any criminal or juvenile justice system. ${ }^{68}$

Skeptics typically respond by arguing that these programs cannot be replicated on a large scale. ${ }^{69}$ This view is understandable, but it is also overly pessimistic. Before explaining why, it is important to examine what skeptics claim is much more relevant and significant, namely the evidence regarding the impact of public, large-scale programs.

\section{Large-Scale Programs}

The most well-known large-scale program, though perhaps the least understood, is Head Start. Although it has been subject to intense scrutiny, there has never been a long-term, large-scale, randomized trial of a "typical" Head Start program. Indeed, the dearth of reliable research led the U.S. General Accounting Office to lament that the large body of research on Head Start "is inadequate for use in drawing conclusions about the impact of the national program in any area where Head Start provides

66. Currie, supra note 6 , at 10-13.

67. See, e.g., Woodhead, supra note 47, at 446-50; Darcy Ann Olsen, Universal Preschool is No Golden Ticket 9 (Cato Inst., Policy Analysis No. 333, 1999), http://www.cato.org/pubs/pas/pa333.pdf.

68. Hancock v. Driscoll, No. 02-2978, 2004 WL 877984, at *137 (Mass. Super. Apr 26, 2004) (emphasis added). A North Carolina trial court reached a similar conclusion. See Hoke County Bd. of Educ. v. State, No. 95CVS1 158, 2000 WL 1639686, at *106-08 (N.C. Super. Oct. 12, 2000) (unpub. op.) (reviewing the "large body of research [that] supports the efficacy of quality pre-kindergarten programs").

69. See supra note 47 and accompanying text. 
services, such as school readiness or health-related services." ${ }^{270}$ In addition, because the program gives local providers a good deal of discretion, and the program has changed considerably in its design and implementation over the course of nearly three decades, there is no single Head Start program to study. ${ }^{71}$ All of these limitations obviously complicate any comprehensive analysis of the impact of Head Start.

Nonetheless, some tentative conclusions can be drawn about the impact of Head Start. Most studies conclude that the program improves IQ, reading, and math scores over the short-run. But these gains tend to fade while children are still in elementary school. ${ }^{72}$ Many studies also indicate, however, that Head Start is effective in reducing grade retention and special education placements. ${ }^{73}$ Some studies have also found that Head Start participants are more likely to graduate from high school. ${ }^{74}$

A comprehensive review of large-scale programs confirmed that they can--but do.not always-produce lasting benefits. As is typically the case with model programs, the IQ of participants increased initially but faded out shortly after the start of school. Increases in achievement scores, however, persisted longer. In most of the studies, achievement increases remained significant at least through third grade. Public programs also significantly reduced grade retention and special education placement. Eight of the ten studies that collected relevant data found statistically significant reductions in grade retention and special education placements. The differences, however, were less than they were for model programs. ${ }^{75}$

Even more definitive and positive conclusions about the benefits of large-scale programs can be drawn from a smaller public program, the Chicago Child Parent Centers (CPCs). The CPC program began in 1967 in eleven Chicago public schools, with Title I funding from the federal government. Three- and four-year-olds attended half-day preschool for nine months each year, and they also received health and social services. In 1978 , with the addition of state funding, the program expanded to provide services through the third grade. Currently, twenty-four centers, all located in public schools, provide services from preschool through first, second, or third grades. The centers are located in the poorest neighborhoods in Chicago. ${ }^{76}$

70. GAO, HEAD START RESEARCH, supra note 41 , at 2 .

71. RAND STUDY, supra note 7 , at 41 .

72. See, e.g., Woodhead, supra note 47, at 446; GAO, HEAD START RESEARCH, supra note 41, at 8; RAND STUDY, supra note 7, at 41-44.

73. Currie, supra note 6, at 33-34.

74. JacQueline M. Royce et AL., Pooled Analyses: Findings Across Studies, in As The Twig IS BENT 440-4I (Consortium for Longitudinal Stud. ed., 1983).

75. These findings are reported in Barnett, Early Childhood Education, supra note 46, at 6-7, and Reynolds et al., Long-Term Effects, supra note 48, at 40-43.

76. This description comes from Reynolds et al., Long-Term Effects, supra note 48, at 2340-41, and RAND STUDY, supra note 7, at 45-47. 
In a recent article published in the Journal of the American Medical Association, researchers reported findings from a longitudinal study of over 1,500 participants, through age twenty-one. Compared to a subsequently selected control group, CPC preschool participants had significantly lower rates of special education placement, grade retention, and juvenile arrests. Participants also scored significantly higher in math and reading tests through age fifteen and were more likely to complete school. ${ }^{77}$ For some of the measures, though not all, students who participated in the program beyond preschool achieved even better results than those who only participated in the preschool component. ${ }^{78}$

This study is especially important because it is one of the few longitudinal studies of a relatively large-scale, public program. Although it does not meet the gold standard of randomized assignment, the researchers used several different statistical methods to control for the possibility of selection bias. Their findings were robust to the use of these different methodologies, lending credence to the researchers' conclusions that their findings "are among the strongest evidence that established programs administered through public schools can promote children's long-term success."79

As the researchers also point out, preschool is not a panacea. CPC participants may fare better than a similarly situated control group, but they still do not compare favorably to national norms, along a number of dimensions. Rates of school dropout and juvenile delinquency, for example, were significantly higher for CPC participants than for children nationally. ${ }^{80}$ From this study and others, of both model and large-scale programs, it nonetheless appears that preschool can provide a strong foundation for learning, and it can bestow long-term benefits. A question that remains to be answered is whether these benefits outweigh the costs of providing preschool.

\section{Targeting}

In order to accurately assess the costs and benefits of preschool, it is necessary to consider two additional issues raised by the research. Both relate to targeting. The first is whether preschool has greater benefits for disadvantaged children, and the second is whether there is an optimal age-three or four-to begin preschool. The answers are yes and no, respectively (and tentatively).

Most researchers agree that preschool offers greater benefits for disadvantaged children, although they are not uniform in defining exactly who is "disadvantaged." Some focus on poverty, some on mothers' education

77. Reynolds et al., Long-Term Effects, supra note 48, at 2343-46.

78. Id: see also RAND STUDY, supra note 7, at 47 .

79. Reynolds et al., Long-Term Effects, supra note 48, at 2339.

80. Id. at 2345 . 
levels, others on health-related factors like birth weight, and still others on intelligence measures like IQ. ${ }^{81}$ Regardless of the factors used for classifying children as disadvantaged, however, studies tend to show that these children benefit more than "middle-class" children, another somewhat amorphous group. ${ }^{82}$ The research here generally confirms what common sense suggests: children who are offcred less at home have more to gain from attending preschool, and children from any number of disadvantaged groups tend to have fewer learning opportunities at home than their more economically advantaged peers. Leading researchers in the field, moreover, agree that high-quality preschool provides greater benefits for poor children, ${ }^{83}$ although they are quick to point out that preschool can benefit all children. ${ }^{84}$

As for when to begin preschool, the highly publicized research on early brain development has led some to conclude that the kcy period for intervention is between birth and three years, when a child's brain undergoes dramatic growth. ${ }^{85}$ From this perspective, intervening at age three may be too late, rather than too early. This view, however, misconstrues the nature of the scientific evidence. While it is true that brain growth-in terms of the number of brain synapses that are formed-is at its highest between birth and age three, ${ }^{86}$ it has not been established that infants need center-based care during this period in order to maximize their chances of future success. ${ }^{87}$ What the research shows instead is that infants subject to trauma and neglect may suffer irrevocable harm, while those offered nurturing care do not. ${ }^{88}$ This is not to say that high-quality child care will harm

81. See Currie, supra note 6 , at 21 .

82. See, e.g., id. at 21-22; RAND STUDY, supra note 7, at 85-96; Reynolds et al., Long-Term Effects, supra note 48 , at 41 ; Goldberg, supra note 6.

83. Currie, for example, agrees that "the benefits of early intervention are greater for more disadvantaged children," but she suggests that the evidence allows only a tentative answer. Currie, supra note 6, at 21. Barnett also agrees that "the research does show greater preschool benefits for poor children." Goldberg, supra note 6; see also Hancock v. Driscoll, No. 02-2978, 2004 WL 877984, at *137 (Mass. Super. Apr. 26, 2004) (reviewing expert testimony, which showed a greater effect of preschool, in terms of school readiness, on poor children than on more economically advantaged children).

84. Barnett, State of Preschool, supra note 2, at 2; see generally From Neurons to NEIGHBORHOODS, supra note 43 (explaining that all children can benefit from high-quality preschool).

85. Currie, supra note 6 , at 6-8, 28.

86. See, e.g., Alison Gopnick et al., The Scientist in the CriB: Minds, Brains, and How ChILdRen LeARn (1999); John T. Bruer, The Brain and Child Development: Time for Some Critical Thinking, 113 Pub. Health Rep. 389 (1998).

87. Currie, supra note 6 , at 6-8, 27-28.

88. Megan Gunnar, Quality of Early Care and Buffering of Neuroendocrine Stress Reactions: Potential Effects on the Developing Human Brain, 27 Preventrve MEd. 208 (1998). 
infants, only that the research fails to establish that early childhood interventions must begin before age three to create a lasting impact. ${ }^{89}$

Current research also fails to answer whether preschool should begin at age three or four. Many preschool advocates argue that it ought to begin at age three. ${ }^{90}$ This position appears motivated less by hard evidence and more by inferences from brain research and the intuition that starting earlier must be better than starting later. ${ }^{91}$ There is little conclusive evidence, however, that beginning at age three is necessary in order to achieve shortor long-term gains in cognitive functioning or academic achievement. Indeed, there have been relatively few reliable studies of this particular question. ${ }^{92}$ The few existing studies come to mixed conclusions: some show additional benefits, and others do not. ${ }^{93}$ A recent study of the Chicago CPCs, for example, found no additional benefits to starting at age three as compared to age four. ${ }^{94}$

To be clear, the research does not establish that starting at age four and providing only one year of preschool is optimal. The available evidence simply does not allow conclusions to be drawn about the optimal age of intervention. What it suggests instead is that "it may be more important to worry about the quality of the intervention, than about the exact timing of it." 95

\section{Costs, Benefits, and Scaling Up}

Cost-benefit analyses of preschool programs have proliferated in the past several years. Researchers have conducted such analyses for a number of preschool programs, including the Perry Preschool Project, the Abecedarian Project, the Chicago CPCs, and Head Start. These studies all attempt to calculate the monetary benefits of preschool for children, their families, and society over the short, medium, and/or long terms, depending

89. Cf. RAND STUDY, supra note 7, at 63-68 (summarizing benefits from a diverse array of early childhood interventions, including ones that began shortly after the child's birth and those that began at ages three and four).

90. See, e.g., CED, Preschool For All, supra note 3, at 1 (calling for universal access to preschool for children age three and over); Bus. RoundTABle \& CORP. VoICEs For Working Families, Early Childhood Education: A Call to Action from the Business Community 1 (2003), http://www.brtable.org/pdf/901.pdf (same) [hereinafter BuSINESS RoundTABLE].

91. See Arthur J. Reynolds, One Year of Preschool Intervention or Two: Does It Matter?, 10 Early Childhood Research Q. 1, 2 (1995) [hereinafter Reynolds, Does It Matter?].

92. Reynolds et al., Long-Term Effects, supra note 48, at 42.

93. Reynolds, Does It Matter?, supra note 91, at 2-4 (reviewing conflicting studies and concluding that they do not offer conclusive evidence of additional benefits to two years of preschool for economically disadvantaged children).

94. Id. at 1. This study found that children with two years of preschool began and ended kindergarten more "academically competent" than those with only one year, but that through the elementary grades the two groups did not differ in terms of academic achievement or social adjustment. The author concluded that, if resources are limited, offering one year of quality preschool is optimal. Id.

95. Currie, supra note 6, at 29. 
on data availability. In the short and medium term, researchers found enhanced academic achievement, a reduction in special education placements, and reduced grade repetition. Over the long term, benefits included a greater likelihood of graduating high school and attending college, better employment and higher wages, lower crime rates, and decreased welfare dependency. ${ }^{96}$

Researchers' conclusions are unanimous: the benefits of model preschool programs exceed the costs. ${ }^{97}$ The cost-benefit ratios, as might be expected, vary quite a bit, depending on the researchers' assumptions about the dollar value of certain benefits, the discount rate employed, the benefits included in the study, and the time period studied..$^{98}$ Even studies using the most conservative estimates, however, typically find that savings to the public alone are more than twice the cost of the program. ${ }^{99}$

The RAND study of Perry Preschool is an instructive example. The researchers focused only on savings to the public that resulted from reduced government expenditures or increased government revenues. They thus looked at reductions in criminal justice and welfare costs, education services, and increases in income tax revenue. Based on these benefits alone, the RAND team concluded that by the time the Perry participants were twenty-seven, the public had saved more than twice what it spent on the program. ${ }^{100}$ These findings have been confirmed by others who have studied Perry Preschool, including a team from the Federal Reserve Bank in Minneapolis. ${ }^{101}$ Indeed, the latter concluded that investing in preschool carries an unusually high rate of return, making it an especially wise public investment-much smarter than, say, investing in a new sports stadium or using tax subsidies to lure businesses to a locality. ${ }^{102}$

Studies of other preschool programs have reached similar conclusions. An evaluation of the Abecedarian Program found that for every dollar invested, society recouped between $\$ 2$ and $\$ 3.66 .^{103}$ An evaluation of the

96. Belfield, supra note 49 , at 1-6.

97. See generally W. Steven Barnett, Lives in the Balance: Age-27 Benefit-Cost ANalysis of the High/Scope Perry Preschool Program (1996); RAND Study, supra note 7, at 91-96; SCHWEINHART ET AL., supra note 52.

98. Barnett, for example, included such benefits as reducing intangible losses-for example, pain and suffering-to crime victims, which helps explain why his benefit-to-cost ratio is higher than the one calculated by the RAND team. RAND STUDY, supra note 7, at 91-98.

99. See $i d$. (explaining use of conservative estimates regarding savings from preschool programs).

100. Id.

101. Art Rolnick \& Rob Grunewald, Early Childhood Development: Economic Development with a High Public Return, FEDGAZETTE, Mar. 2003, http://minneapolisfed.org/pubs/fedgaz/0303/earlychild.cfm.

102. Id.

103. L.N. Masse \& W. Steven Barnett, A Benefit-Cost Analysis of the Abecedarian Early Childhood Intervention, in Cost-EFFeCTIveness AND EduCATIONAL Policy 157 (Henry Levin and P.J. McEwan eds., 2002). 
Chicago CPCs found even greater returns, which is especially encouraging given that the CPCs were not a model program. A cost-benefit study of the CPCs found that for every dollar invested, $\$ 7.14$ was recouped in benefits. ${ }^{104}$ Finally, one economist calculated just the short- and medium-term benefits of Head Start (data was not available for long-term benefits), and concluded that the short- and medium-term benefits would offset $40 \%$ to $60 \%$ of the costs. ${ }^{105}$

Another recent study by Clive Belfield, an economist at Teachers College of Columbia University, calculated the medium-term cost savings to a school system from having a universal preschool program. ${ }^{106}$ His study is particularly helpful because it examines what a school system could expect to recoup over a relatively short time period-approximately ten years-if it instituted a preschool program for all children. Reviewing prior studies, Belfield found that school systems could save between $\$ 2,591$ and $\$ 9,547$ per child, primarily from reduced special education placement and grade repetition. ${ }^{107}$ Belfield then used these past studies to model the returns to a universal preschool program that spent $\$ 7,000$ per child. He concluded that the average medium-term benefits, just to the school system, would offset between $40 \%$ and $60 \%$ of the costs. ${ }^{108}$

These cost-benefit analyses are useful to bear in mind when considering the important question of whether high-quality preschool programs can be reproduced on a large scale. Skeptics often point to the resources devoted to model programs like Perry Preschool and argue that they cannot be replicated on a large scale. ${ }^{109}$ What skeptics often fail to acknowledge, however, is that even the Perry Preschool program did not cost an exorbitant amount. In 1999 dollars, the program cost about $\$ 7,000$ per child, which was only slightly higher than the average amount spent per child in K-12. ${ }^{110}$ The Chicago CPCs ${ }^{111}$ and Head Start programs ${ }^{112}$ cost even less.

These figures indicate that turning a high-quality model program into a universal one is financially feasible though not cheap. They suggest that

\footnotetext{
104. Belfield, supra note 49 , at 7.

105. Janet Currie, Early Childhood Programs, 15 J. Econ. Perspectives 213, 233-35 (2001)

106. Belfield, supra note 49 , at 1 .

107. Id. at 9 tbl. $1,13$.

108. Id. at 21 .

109. See supra note 47 and accompanying text.

110. Currie, supra note 6 , at 14 n.6. The national average expenditure per $\mathrm{K}-12$ pupil was $\$ 6,508$ in 1999. NCES, Digest of EduCATION STATISTICs, supra note 3, at 37 tbl.33.

111. The figures are not perfect for comparison, but a rough estimate places them below the cost of Perry Preschool. The average expenditure in 1996 for one year of preschool in the CPCs was $\$ 4,350$, see Reynolds et al., Long-Term Effects, supra note 48, at 2342, and the average expenditure in 1998 dollars for 1.5 years of preschool was \$6,730, see CED, PRESCHOOL fOR ALL, supra note 3, at 21.

112. Head Start cost an average of $\$ 5,951$ in 2000. CED, PRESCHOOL FOR ALL, supra note 3, at
} 10 . 
spending about $\$ 8,000$ per child, ${ }^{113}$ roughly the same amount of funding now spent on K-12 children, should be sufficient to create high-quality preschools.

If this seems too expensive an investment, consider that states currently spend about the same per-pupil amount on higher education as spent on K-12 schooling, leading to a total investment of over $\$ 60$ billion in higher education. ${ }^{114}$ This is twenty-five times the amount states currently spend on preschool. ${ }^{115}$ For about the same amount of money they invest in higher education, states could provide high-quality preschool to all threeand four-year-olds. ${ }^{116}$

A multi-billion dollar expenditure is substantial, no matter how it is viewcd. But this expense, it bears emphasizing, would be partially offset in the medium term by savings to $\mathrm{K}-12$ education. Moreover, the cost of providing preschool could be reduced by roughly half if it were offered only to four-year-olds, and costs could be further reduced if preschool were offered only to disadvantaged four-year-olds. As discussed above, the social science research suggests that poorer students benefit the most from preschool, and it is inconclusive about the optimal age to begin preschool. ${ }^{117}$ Taken together, this suggests that the most cost-effective policy may be to create high-quality preschools for all poor four-year-olds. There would indeed be additional benefits to providing universal access to preschool for all three- and four-year-old children, but the marginal benefits may not exceed the marginal costs.

In sum, the benefits of one year of preschool, especially for disadvantaged children, easily outweigh the costs. To be sure, there will be tradeoffs if preschool is fully funded. It may be that other programs or services would have similar or even better benefit-cost ratios. But there is simply not enough research to make these sorts of comparisons in an effort to

113. See Nat'l Ctr. for Educ. Stats., U.S. Dep't. of Educ., Projections of Education STATISTICS To 2013, at 81 (32d ed. 2003).

114. For fiscal year 2004, the total state appropriations for operating expenses of higher education were $\$ 60,694,185$. For fiscal year 2005 , that number was $\$ 63,005,272$. James C. Palmer, Grapevine: An Annual Compilation of Data on State Tax Appropriations for the General Operation of Higher Education, 50-state Summary Table, http://www.coe.ilstu.edu/grapevine/50state.htm (last visited Aug. 31, 2005). The total federal appropriation for postsecondary education was $\$ 24,678,534$ in FY2004 and $\$ 28,266,842$ in FY2005. These amounts are roughly three times the amount the federal government spends on Head Start. U.S. DeP'T of EduC., UNITEd States Education DePartment BUDGET HISTORY TABLE FY 1980-PRESENT, http://www.ed.gov/about/overview/budget/history/ edhistory.pdf (last visited Aug. 11, 2005).

115. See BARNeTt supra note 2, at 5 .

116. See CED, PrESChOol For ALL, supra note 3, at 36 (estimating that universal access to preschool for three- and four-year-olds, funded between $\$ 4,000$ and $\$ 5,000$ per pupil, would cost between $\$ 33.2$ and $\$ 41.5$ billion per year). If the 8.3 million eligible children werc all provided preschool, funded at the higher lcvel of $\$ 8,000$ per child, the total cost would be roughly $\$ 66$ billion. See id.

117. See supra notes 90 through 94 and accompanying text. 
achieve the optimal mix of interventions. What the research strongly suggests is that, as a matter of policy, providing at least one year of preschool to economically disadvantaged children would be a very wise public investment. In addition, if the inevitable tradeoff that accompanies new spending is limited to the field of education, the documented returns to preschool participation suggest that shifting some funding to preschool would be beneficial, and that the tradeoff would be minimized by increased savings to schools.

Governors and state legislatures seem to appreciate this point, as they have expanded access to preschool over the past ten years. But many disadvantaged children remain out of preschool because public programs are full and their parents cannot afford private programs. It may be that, over time, legislatures on their own would ensure access for all poor children in their states. In the meantime, however, it is worth considering whether children have a legal right of access. The first place to look is to state constitutions.

\section{II}

\section{The Legal Case for Preschool}

All state constitutions contain an education clause. These clauses require legislatures to create and maintain a system of free, public schools, and thereby establish a corresponding right to a free, public education. As discussed in this Part, the text and history of these clauses do not resolve the question of whether children have a right of access to preschool. These clauses, however, have been interpreted by roughly twenty state courts of last resort to guarantee students a right either to adequate or equal educational opportunities, and to guarantee schools the funding necessary to provide those opportunities. The legal argument for a right to preschool, already entertained by courts in four states, builds upon these funding cases. There are two basic theories upon which a right of access can rest. The first is that preschool is an important component of an adequate education. The second is that equal educational opportunity requires offering preschool to all children, or at least to all disadvantaged children.

\section{A. Text and History}

State education clauses require state legislatures to establish a system of public schools. ${ }^{118}$ The precise language of these clauses varies. Some

118. See Ala. Const. art. XIV, § 256; Alaska Const. art. VIl, § 1; ARIz. Const. art. XI, § 1; ARK. Const. art. XIV, § I; Cal. Const. art. IX, § 1; Colo. Const. art. IX, § 2; Conn. Const. art. VIII, § 1; Del. Const. art. X, § I; Fla. Const. art. 1X, § 1; GA. Const. art. VIII, § 1; Haw. Const. art. X, § I; Idaho Const. art. IX, § 1; ILl. Const. art. X, $\S 1$; IND. Const. art. VIll, § 1; Iowa Const. art. IX, 2d, § 3; KAN. Const. art. VI, § 1; Ky. Const. § 183; LA. Const. art. VIII, § 1; Me. Const. art. VIII, pt. 1, § 1; MD. Const. art. VIII, $\S 1$; Mass. Const. pt. 2, ch. 5, § 2; Mich. Const. art. VIlI, $\S 2$ Minn. Const. art. XIII, $\S 1$; Miss. Const. art. VIII, $\S 201$; Mo. Const. art. IX, § 1(a); MonT. Const. 
clauses impose clearer, more ambitious duties on state legislatures than do others. ${ }^{119}$ Nonetheless, many states use similar phrases to qualify the legislature's duty, typically commanding them to establish a system of free public schools that is "general and uniform," "thorough and efficient," or some combination of these adjectives. ${ }^{120}$ Georgia's requirement of an "adequate" system of public education is unique, ${ }^{121}$ as is Montana's constitutional guarantee of "equality of educational opportunity ... to each person of the state." 122

Most clauses are silent about who is entitled to an education. Only seven states specify age limits. Alabama extends the right of public education to those between the ages of seven and twenty-one. ${ }^{123}$ Arkansas and Colorado guarantee public education to those between six and twenty-one, while Nebraska and New Jersey extend that right to those between five and twenty-one. ${ }^{124}$ By contrast, Wisconsin provides that public education will be free "to all children between the ages of 4 and 20 years," 125 and Florida has recently extended the right of education to four-year-olds. ${ }^{126}$

A few other state constitutions suggest that public school begins with kindergarten, while others indicate that it might begin earlier. The Arizona Constitution, for example, states that public schools must include "kindergarten schools, common schools, high schools, normal schools, industrial schools, and a university," which strongly implies that the system need not include preschools. ${ }^{127}$ The constitutions of Montana and North Dakota similarly suggest that public education begins with "elementary" or "primary" schools. ${ }^{128}$ By contrast, seven state constitutions require that a free education must be provided to "all children" of the state,

art. X, § 1; NEb. Const. art. VII, § 1; NEv. Const. art. XI, § 2; N.H. ConST. pt. 2, art. LXXXIII; N.J. Const. art. VIII, $\S 4$, 1 ; N.M. Const. art. XII, § 1 ; N.Y. ConsT. art. XI, § 1; N.C. Const. art. IX, 2; N.D. Const. art. VIII, § I; OhIo Const. art. VI, § 3; OKla. Const. art. XIII, § I; Or. Const. art. VIII, § 3; PA. Const. art. III, § I4; R.1. Const. art. XII, § 1; S.C. Const. art. XI, § 3; S.D. Const. art. VIII, $\S 1$; Tenn. Const. art. XI, § 12; TeX. Const. art. VII, $\$ 1$; UtAH Const. art. X, $\S 1$; VT. Const. ch. $2, \S 68$; VA. Const. art. VIII, $\S I$; WASH. Const. art. IX, $\S 1$; W. VA. ConsT. art. XII, $\S 1$; WIS. Const. art. X, § 3; Wyo. Const. art. VII, $\S 1$.

119. See, e.g., John Dayton, Serrano and its Progeny: An Analysis of 30 Years of School Funding Litigation, 157 EDUC. L. REP. 447, 457-58 (2001) (placing education clauses into four categories, depending on their "strength"); Gershon Ratner, A New Legal Duty for Urban Public Schools: Effective Education in Basic Skills, 63 TEx. L. REv. 777, 815-16 (1985).

120. For a useful compilation of state education clauses, see Hamilton Fish Institute, Review of State Constitutions: Education Clauses (2000), http://www.hamfish.org/pub/ revedcl.pdf.

12I. GA. Const. art. VIII, $\S 1$.

122. Mont. Const. art. X, $\S 1$.

123. ALA. ConSt. art. XIV, $\S 256$.

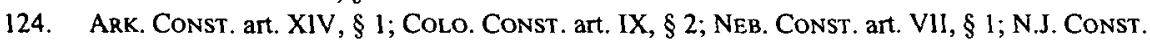
art. VIII, $\$ 4$.

125. Wis. Const. art. X, $\S 3$

126. See supra note 33 and accompanying text.

127. ARIZ. Const. art. XI, § 1 .

128. Mont. Const. art. X, $\S 1$; N.D. Const. art. VIII, $\S 1$. 
or, in Louisiana's formulation, to persons "at all stages of human development."129 Two other states, New Mexico and Virginia, straddle the line by requiring that education be available to "all children of school age," without specifying that age. ${ }^{130}$

As this overview indicates, only the few state constitutions that specify age limits offer real guidance as to who is eligible to receive a free education. The state constitutions that guarantee an education to "all children" of the state might seem to require some form of preschool, but even a strict textualist would have difficulty reading these clauses literally. It seems implausible to imagine, for example, that these provisions guarantee that every two-year-old in the state has a right of access to public school.

Even those state constitutions that specify age limits have not generated predictable court interpretations. Indeed, the two relevant decisions on this issue are precisely contrary to what one would expect. On the one hand, the New Jersey Supreme Court created a "quasi-constitutional" right to preschool for some three- and four-year-old children, despite the plain language of the education clause limiting the right of public education to children ages five and older. ${ }^{131}$ On the other hand, the Wisconsin Supreme Court concluded that the provision guaranteeing "all children" four and older a free education does not actually require districts to provide school for four-year-olds. ${ }^{132}$

The drafting history of the education clauses does not shed much light on eligibility requirements. The history is generally sparse, in part because many states borrowed provisions from their neighbors, ${ }^{133}$ and is almost uniformly unhelpful. ${ }^{134}$ It appears that those who drafted and ratified these clauses typically did not discuss the age at which children would be entitled to an education. We can nonetheless be confident that few, if any, drafters or ratifiers would have contemplated preschool, given that publicly funded preschool is a relatively recent phenomenon which postdates the drafting of state education clauses.

At the same time, however, the history does not preclude the possibility of eligibility requirements changing as society and the need for education change. ${ }^{135}$ One searches the drafting history in vain for indications that

129. Alaska Const. art. VII, § 1; La. Const. art. VIII, § 1; Mo. Const. art. IX, § 1(a); OKLa. Const. art. XIII, § 1; S.C. Const. art. XI, § 3; UTAH Const. art. X, § I; WASH. Const. art. IX, §1.

130. N.M. ConST. art. XII, $\S 1$; VA. CONST. art. VIII, $\S 1$.

131. Abbott v. Burke, 710 A.2d 450, 461-62 (N.J. 1998).

132. Zweifel v. Joint Dist. No. 1, 251 N.W.2d 822, 826-27 (Wis. 1977).

133. A.E. Dick Howard, Introduction: A Frequent Recurrence to Fundamental Principles in Developments In State Constitutional Law, in Developments in State Constitutional Law xiii (Bradley D. McGraw ed., 1985).

134. See William E. Thro, The Role of Language of the State Education Clauses in School Finance Litigation, 79 Educ. LAW REP. 19, 22 \& n.22 (1993).

135. Cf. DeRolph v. State, 728 N.E.2d 993, 1001 (Ohio 2000) ("The definition of [a] 'thorough and efficient' [education] is not static. What was deemed thorough and efficient when the state's 
the length of schooling was to be fixed in stone for all time. Similarly, if one consulted the general understanding of who was entitled to education at the time the clauses were drafted or ratified, that understanding surely would have been tied to the degree of edueation then provided. But it is hard to conclude from this fact alone that the original understanding of these clauses-assuming one is interested in original understandingprecludes an expansion of the right as the need for schooling expands. ${ }^{136}$

A more plausible inference from the text and history is that legislatures have some discretion in deciding when public schooling should begin. Although case law on the issue of eligibility for public schools is sparse, the few reported decisions suggest that legislatures have ample authority to set age requirements for school attendance. ${ }^{137}$

At the same time, however, it is illogical to suppose that legislatures have unfettered discretion to set eligibility requirements. Imagine the extreme case of a state legislature that decided public education would be available only to those between the ages of eight and ten. Such a limitation would make a mockery of the right to a public education. The simple requirement that legislatures maintain a system of public schools, whether "general and uniform" or "thorough and efficient," must limit the degree to which legislatures can constrain eligibility for public education. That is, the explicit textual guarantee of an education must contain an implicit guarantee of at least a minimally adequate education, unless the language is unenforceable or a sort of joke.

Thus, an external principle, linked either to the need for the educational service or to equality, must constrain a legislature's determination of eligibility for educational services. (And, indeed, this basic point forms the foundation for any and all legal claims to preschool, insofar as all claims will ultimately rest on the notion that principles of equity or adequacy require that access to preschool be expanded.). Unless courts decide that education clauses are simply non-justiciable, which very few have, ${ }^{138}$ it cannot be the case that legislatures have complete freedom to determine eligibility requirements. Such a power would effectively be the power to

Constitution was adopted certainly would not be considered thorough and efficient today."). Similar statements appear in opinions of the New Jersey, New Hampshirc, Vermont, and New York high courts. See Deborah A. Verstegen, Towards a Theory of Adequacy: The Constitutional Saga of Equal Educational Opportunity in the Context of State Constitutional Challenges to School Finance Systems, 23 ST. Louis U. Pub. L. Rev. 499, 509-10 (2004).

136. Cf. Hancock v. Comm'r of Educ., 822 N.E.2d 1134, 1140 (Mass. 2005) ("The framers rccognized that the content of the duty to cducate ... will evolve together with our society, and that the education clause must be interpreted in accordance with the demands of modem society or it will be in constant danger of becoming atrophied and, in fact, may even lose its meaning.") (internal quotations omitted).

137. See, e.g., Simonson v. Sch. Dist. No. 14, 258 P.2d 1128 (Colo. 1953); Hoke County Bd. of Educ. v. State, 599 S.E.2d 365, 391 (N.C. 2004); Detch v. Bd. of Educ., 117 S.E.2d 138 (W. Va. 1960).

138. Verstegen, supra note 135 , at 508. 
unilaterally interpret and enforce the various education clauses in state constitutions.

In addition, it is important to recognize that legislatures in forty states have already provided publicly funded preschool to some children. As discussed in greater detail below, this may make the issue of age eligibility largely irrelevant, insofar as the legislature's action may be a tacit acceptance that preschoolers are entitled to educational services. Indeed, it is hard to understand how else to interpret a state's decision to provide publicly-funded preschool other than as an agreement to provide education to some four-year olds. To the extent this interpretation is correct, the relevant question is not whether courts can lower age-eligibility requirements, but whether legislatures, having already effectively done so, can pick and choose which preschool-age children receive a publicly funded education.

The only point to recognize, for now, is that the text and history of education clauses do not resolve preschool claims-just as they do not fully resolve more general claims for increased funding. To be sure, one could make text-based arguments for a right to preschool, especially in those few states that guarantee a right of education for four-year olds. Even in states that are silent on age eligibility but nonetheless guarantee the right to a "thorough and efficient" system of schools, text-based arguments are available. One could argue, for example, that a school system is neither thorough nor efficient absent preschool. ${ }^{139}$ On the other hand, one could make text-based arguments against a right to preschool in those few states, like New Jersey, where the constitution explicitly limits the right of public education to those five and older. Absent explicit language in either direction, however, intellectual honesty compels the conclusion that neither the language nor the history is determinate. The language and history do not obviously entitle all children to preschool, nor do they foreclose recognition of such a right.

Given that a right to preschool is neither foreclosed nor guaranteed by text or history, the next place to turn is precedent. This is where things get especially interesting.

\section{B. Precedent}

Decisions regarding school-finance systems comprise the most relevant precedents. Since the late 1960 s, litigants have challenged the equity and adequacy of school funding systems. ${ }^{140}$ In 1973, the U.S. Supreme Court effectively closed the door to federal relief in San Antonio $v$.

139. Cf. Lake View Sch. Dist. No. 25 v. Huckabee, No. 01-836, 2004 WL 1406270 (Ark. June 18, 2004) (acknowledging conclusion of special masters that "research shows if a child is not proficient by the fourth grade, money spent on remediation which was not spent on early-childhood education would have a much lower chance of bringing the child to a proficiency level") (internal quotation omitted).

140. Ryan, Schools, Race, and Money, supra note 9, at 253. 
Rodriguez. ${ }^{141}$ In that decision, the Court upheld Texas' unequal school funding scheme against an equal protection challenge. The Court concluded that education is not a fundamental right and that Texas' funding system furthered the state's legitimate interest in promoting local control.

Undeterred, litigants turned to state courts, where they have experienced a good deal of success. At first, litigants primarily argued that education and equal protection provisions in state constitutions guaranteed students a right to equal educational opportunity. Plaintiffs typically requested some sort of equalized funding as relief. Results in these so-called equity suits were, and continue to be, mixed. Plaintiffs have prevailed in nine states, while they have lost equity cases in seventeen. ${ }^{142}$

In the late 1980s, most advocates abandoned equity claims and began raising adequacy claims. Instead of arguing that state constitutions guaranteed a right to equal educational opportunity, advocates argued that they entitled all children to an adequate education. ${ }^{143}$ Adequacy claims have focused exclusively on state education clauses and have requested as relief the funding necessary to ensure all children the opportunity to receive an adequate education. Results in adequacy cases have been more favorable to plaintiffs, with success in eleven states and losses in only five. ${ }^{144}$

All told, school finance plaintiffs have prevailed in roughly twenty states, while they have lost in a bit more than twenty. It is important to notice that most of the losses came in cases advancing equity rather than adequacy claims. Given that litigants in a number of states have succeeded in adequacy cases after losing equity cases, ${ }^{145}$ the story of school-finance litigation is hardly complete in those states that have heard only unsuccessful

141. 411 U.S. 1 (1973).

142. For a collection of these cases and further discussion, see William S. Koski, Of Fuzzy Standards and Institutional Constraints: A Re-Examination of the Jurisprudential History of Educational Finance Reform Litigation, 43 SANTA ClaRA L. REv. 1185,1189 n.9, 1191 n.14 (2003); McUsic, supra note 19, at 1345-46 \& n.72 (2004); Ryan, Schools, Race, and Money, supra note 9, at 266-68.

143. For further discussion of the trends in school-finance cases, see, for example, James E. Ryan \& Thomas Saunders, Foreword to Symposium on School Finance Litigation: Emerging Trends or New Dead Ends?, 22 YALE L. \& PoL'y Rev. 463, $465-68$ (2004) [hereinafter Ryan \& Saunders]; Ryan, Schools, Race, and Money, supra note 9, at 266-72.

144. Karen Swenson, School Finance Reform Litigation: Why Are Some State Supreme Courts Activist and Others Restrained?, 63 ALB. L. REv. 1147, 1149 (2000). 1 should note that the dividing line between equity and adequacy decisions is often blurrier than this discussion-and most commentators-suggest. Some courts combine principles of equity and adequacy in their decisions, requiring, for example, that "students have a fundamental right to an equal opportunity for a sound basic education." Vincent v. Voight, 614 N.W.2d 388, 396 (Wis. 2000). For further discussion of this point, see Koski, supra note 142, at 193; Ryan \& Saunders, supra note 143, at 468-69. For analytical purposes, it remains useful to distinguish between adequacy and equity claims; the fact that some courts might blend these principles should not affect the outcome of preschool cases, given that both principles support expanding access.

145. See, e.g., Campaign for Fiscal Equity, Inc. v. State, 801 N.E.2d 326 (N.Y. 2003) (upholding adequacy claim after same court, in earlier decision, had rejected equity claim). 
equity suits. ${ }^{146}$ More generally, it bears emphasizing that school finance litigation is rarely resolved in one trip to a state's highest court. In many states, litigants return to court numerous times to work out remedies or test different theories. For these reasons, school-finance litigation continues apace, with active litigation in twenty-three states. ${ }^{147}$ Thus, there are and will continue to be plenty of opportunities to pursue preschool claims.

School-finance suits, not surprisingly, are about funding, which might make some readers wonder how these cases can help preschool advocates. The key is to recognize that the underlying rights in these cases need not be defined solely in terms of money. ${ }^{148}$ The rights recognized in school finance decisions are rights either to equal or adequate educational opportunities. To be sure, the remedies requested tend to focus on funding levels (although some courts have also focused on specific inputs like class sizes). But funding remedies do not exhaust the scope of the underlying rights at stake in school finance cases. ${ }^{149}$ The key question, then, is whether access to preschool should be considered part and parcel of the right to an adequate education or the right to equal educational opportunities.

\section{Preschool and the Right to an Adequate Education}

The right to an adequate education could support two different claims to preschool. One would be broadly based, arguing for a universal right of access. The other claim would be targeted toward disadvantaged children. I discuss each in turn.

Adequacy cases in the school finance arena essentially involve two conceptual steps. The first is to define the goals of an adequate education, and the second is to determine the resources necessary to reach those goals. Courts vary a good deal in how they approach both steps. Some articulate broad end goals, for example, while others set a series of intermediate goals, sometimes looking to academic standards established by state legislatures to help define the contours of an adequate education. ${ }^{150}$ Similarly, when it comes to resources, some courts simply admonish legislatures to

146. A number of courts that have rejected claims to equal funding have explicitly left the door open for adequacy claims. The Supreme Courts of Virginia, Maine, Minnesota, and Wisconsin, in the course of rejecting claims to equal funding, pointed out that plaintiffs failed to demonstrate that the education provided was inadequate, suggesting that relief might be available upon such a showing. See Sch. Admin. Dist. 1 v. Comm'r, 659 A.2d 854, 857 (Me. 1994); Skeen v. State, 505 N.W.2d 299, 30203 (Minn. 1993); Scott v. Commonwealth, 443 S.E.2d 138, 140, 142 (Va. 1994); Kukor v. Gover, 436 N.W.2d 568,582 (Wis. 1989).

147. School Finance Litigation, Educ. WK., Dec. 8, 2004, at 32 tbl.1, available at http://www.edweek.org/ew/articles/2004/12/08/15. The publication of this table preceded the Massachusetts Supreme Court's recent decision, Hancock v. Comm'r of Educ., 822 N.E.2d 1134 (Mass. 2005), which lowers the number reported in the table from twenty-four to twenty-three.

148. James E. Ryan, Sheff, Segregation, and School Finance Litigation, 74 N.Y.U. L. REv. 529, $546-48$ (1999).

149. Id.

150. See Ryan \& Saunders, supra note 143 , at $472-78$. 
provide sufficient funding. Others require legislatures to conduct a costingout study to determine the proper level of funding. Some courts have gone even further and ordered that states provide additional resources to children who are economically disadvantaged or otherwise at risk of failure. ${ }^{151}$

The key point to recognize about these cases is that they require the articulation of an outcome goal or series of goals and some demonstration that a particular input is helpful to reach the goal(s). Importantly, courts do not require plaintiffs to demonstrate that a certain input is absolutely necessary to reach a specific outcome. The social science evidence regarding the relationship between particular inputs and outcomes is notoriously conflicted. ${ }^{152}$ If courts required plaintiffs to show that a certain input or a particular level of funding were absolutely necessary to reach a particular outcome, all adequacy cases would fail. Instead, courts either order general spending levels that appear adequate in light of what successful schools spend, or they order particular inputs, such as small class sizes, that have some proven pedagogical value. ${ }^{153}$

By now, the architecture of a claim to preschool should be apparent: the input of preschool is strongly related to a number of outcomes that are or should be included in any definition of an adequate education. Preschool has both short-term benefits, such as increased readiness for kindergarten and first grade, and long-term benefits, such as decreased placements in special education and decreased grade-retention. It can also increase the chances of high school graduation and college attendance and can improve future employment opportunities..$^{154}$

These short- and long-term outcomes should all be considered components of an adequate education. Indeed, many have already been incorporated in court definitions of adequacy, ${ }^{155}$ and none is controversial or requires an especially expansive conception of adequacy. School readiness is crucial to school success because those who begin behind tend to stay behind or fall even further behind. Avoiding special education placements and grade retention is integral to an adequate education because an adequate education must prepare students to advance from grade to grade within the regular curriculum. Graduating from high school must also be a component of an adequate education; clearly, a school system that fails to enable students to graduate from high school cannot be considered

151. Id.

152. See Ryan, Schools, Race, and Money, supra note 140, at 289-93; see generally THE Brookings Institution, Does Money Matter? The Effect of School Resources on Student ACHIEvement AND Adult Success (Gary Burtless ed., 1996).

153. See infra note 156.

154. See, e.g., supra note 51 and accompanying text.

155. See, e.g., Hoke County Bd. of Educ. v. State, 599 S.E.2d 365, 386 (N.C. 2004) (examining academic performance, dropout rates, graduation rates, need for remedial help, ability to compete in job markets, and ability to compete in college as evidence of whether students were receiving a constitutionally adequate education). 
adequate. Similarly, an adequate education should prepare students to attend college or enter the workforce.

As long as some or all of these short- and long-term goals are considered part of the definition of "adequacy," there is a very strong argument that preschool ought to be included within a student's right to an adequate education. The simple reason is that preschool helps students achieve every one of these goals.

The social science evidence is not sufficiently strong to conclude that preschool is absolutely necessary for all children, but few-if anyeducational interventions could meet this exacting a standard. More to the point, the research is strong enough to conclude that preschool offers equal or greater benefits than many interventions ordered as part of adequacy cases, such as increased funding generally, smaller class sizes, or improved facilities. ${ }^{156}$ Given the price tag of many of these interventions, moreover, preschool may be one of the most cost-effective and efficient inputs that a court could order. ${ }^{157}$

A strong legal case, therefore, can be made for including universal preschool in any definition of the right to an adequate education. While the social science evidence suggests that disadvantaged children benefit the most from preschool, this does not foreclose recognizing a right of universal access. A number of educational inputs, such as smaller class sizes, also provide greater benefits to disadvantaged students. ${ }^{158}$ Yet because these interventions also provide some benefit to all students, courts typically do not limit their provision to disadvantaged children. ${ }^{159}$ Preschool need not be treated differently from these other inputs, given that it, too, provides benefits for all children.

At the same time, however, the tilt of the social science evidence does give courts and litigants the option of pursuing a more targeted intervention. Some courts and advocates may worry about the costs and political plausibility of ordering universal access to preschool. As a result, they may be more attracted to programs that focus on serving disadvantaged

156. See, e.g., Abbott v. Burke, 710 A.2d 450 (N.J. 1998) (considering funding levels, class sizes, and facilities in determining whether school finance system is constitutional); State v. Campbell County Sch. Dist., 19 P.3d 518 (Wyo. 2001) (same).

157. The New Jersey Supreme Court, for example, ordered the state to spend billions of dollars to repair inadequate facilities and to build new ones. Abbott, 710 A.2d at 526 . The legislature ultimately allocated $\$ 6$ billion for facilities funding. Alexandra Greif, Politics, Practicalities, and Priorities: New Jersey's Experience Implementing the Abbott V Mandate, 22 YALE L. \& POL'Y Rev. 615, 637 (2004).

158. Bruce J. Biddle \& David C. Berliner, What Research Says About Small Class Sizes and Their Effects, POL'Y PERSP., 2002, at 14, available at http://www.wested.org/online_pubs/small_classes.pdf.

159. See, e.g., Campbell, 19 P.3d at $541-44$ (recognizing that studies indicate "that smaller class size can boost student achievement, particularly among at risk children," but not limiting its conclusions regarding appropriate class size to disadvantaged children); Hancock v. Driscoll, No. 022978, 2004 WL 877984, at *141 (Mass. Super. 2004) (same); Campaign for Fiscal Equity, Inc. v. State, 801 N.E.2d 326, 335-36 (N.Y. 2003) (same). 
children, on the theory that such programs are more politically feasible and cost-effective.

This leads to the second approach, as those interested in more targeted programs also have a strong legal argument. The idea is simple and comports with both intuition and social science evidence: disadvantaged children need more assistance in order to obtain an adequate education. Although still unusual, some courts in adequacy cases have begun to pay attention to the additional needs of poor children and others who may be at risk of educational failure. ${ }^{160}$ These courts have ordered states to provide extra resources and programs to address those needs. The basic rationale, again, is that reaching the outcome goals of adequacy requires offering more help to those who need it.

Preschool fits perfectly within this narrower conception of adequacy. Its benefits to disadvantaged children are well established in the social science literature. To the extent that the right to an adequate education requires offering additional help to those who need it, preschool's documented benefits should put it at or near the top of the list of programs. Indeed, this may explain why some courts, in the context of adequacy suits, have already focused on preschool.

Relying on a version of this targeted adequacy theory, four different state courts-Arkansas, New Jersey, Massachusetts, and North Carolinahave recognized a right to preschool. In New Jersey, the Supreme Court granted a right to preschool to threc- and four-year-olds in poor, urban districts. $^{161}$ In Massachusetts, a trial court determined that the state should provide free access to preschool for all at-risk three-and four-year-old children whose parents cannot afford private preschool. ${ }^{162}$ A North Carolina trial court ordered preschool for all disadvantaged four-year-olds in the state, ${ }^{163}$ and an Arkansas trial court similarly suggested that preschool should be provided to disadvantaged children. ${ }^{164}$

The three trial court decisions have been overturned. The Arkansas Supreme Court reversed the trial court's decision because of a unique provision in the Arkansas Constitution, which clearly provides the legislature discretion to fund or not fund preschool. ${ }^{165}$ The North Carolina Supreme Court concluded that it was premature to order access to preschool. ${ }^{166}$ Most recently, the Massachusetts Supreme Court concluded that, at least for the

160. See Ryan \& Saunders, supra note 143 , at $468-72$.

161. Abbott, 710 A.2d at 461-62.

162. Hancock, 2004 WL 877984, at *136-46 \& n.221.

163. Hoke County Bd. of Educ. v. State, No. CVS1158, 2000 WL 1639686, at *112-13 (N.C. Super. Oct. 12, 2000) (unpublished opinion).

164. Lake View Sch. Dist. No. 25 v. Huckabee, 91 S.W.3d 472, 500-02 (Ark. 2002) (discussing trial court's unpublished opinion).

165. Id.

166. Hoke County Bd. of Educ. v. State, 599 S.E.2d 365, 392-95 (N.C. 2004). 
time being, any decision to increase access to preschool should be left to the legislature. ${ }^{167}$ The issue of a legal right of access to preschool has thus been resolved in two states, one in favor of access and one against, while it remains unresolved in two others.

Although not all remain good law, the four favorable rulings are nonetheless instructive to consider together because all employed similar reasoning. Each court reasoned backward from the idea that an adequate education entails achieving certain academic goals, such as reading, basic math skills, advancing from one grade to the next, and graduating from high school. Relying on social science studies, they then observed that "at-risk" children begin school behind their more affluent peers, and that this gap often grows larger as schooling continues. Poor children who have attended high-quality preschools, by contrast, begin school on more equal footing. They are therefore more likely to achieve the academic milestones that constitute an adequate education. Thus, in order to ensure that all children have a reasonable opportunity to obtain an adequate education, these courts concluded that "at-risk" children must be provided at least a year of preschool. ${ }^{168}$

Although these courts may have slightly oversimplified the issues, their reasoning is persuasive and consistent with intuition, social science, and even basic ideas of fairness. Ultimately, these courts agreed that in order to receive an adequate education, students must begin kindergarten and first grade prepared to learn. If they do not, they head toward a path of academic failure. ${ }^{169}$ If students do enter school prepared, a different snowball effect can occur, in which students experience academic success and are inspired to achieve. Their teachers and parents, in turn, may witness the

167. The court's decision is a little hard to decipher, in part because it is a split decision, and in part because none of the justices devotes much attention to the specific issue of access to preschool. Three justices concluded that it was inappropriate to intervene at this point, given the progress the legislature had made in reforming the educational system in response to an earlier school finance decision; these justices also suggested that whether to provide preschool education was a "policy decision" for the legislature, at least for the moment. See Hancock, 2005 WL 332016, at *3, *17-18. Two other justices would cut back on the court's expansive reading of the Education Clause in an earlier decision, see id. at *19-24, while two other justices would order a study to determine-among other things-the costs of increasing access to preschool, see id. at *28. Taken together, five out of seven justices would seem to agree that, at the very least, increased access to preschool might someday be ordered by the court.

168. See Lake View, 91 S.W.3d at 500-02; Hancock, 2004 WL 877984, at *136-46 \& n.221; Abbott v. Burke, 710 A.2d 450, 461-62 (N.J. 1998); Hoke, 2000 WL 1639686, at *112-13.

169. This intuition played a strong role in motivating the North Carolina trial judge, Howard Manning, to request that plaintiffs include a claim for preschool in their complaint. A Republican, Manning explained recently that his experience in sentencing juvenile drug dealers, "most of them black and most of them poor," convinced him "that something is not right and you've got to do something with them early." Tico A. Almeida, Refocusing School Finance Litigation on At-Risk Children: Leandro v. State of North Carolina, 22 YALE L. \& Pol'y Rev. 525, 535 n. 74 (quoting Judge Manning). 
child's satisfaction and engagement with school and become more motivated to help them succeed. ${ }^{170}$

Notice that this analytical approach to the adequacy claim can render irrelevant the issue of age eligibility for public education. Under this conception, preschool is a supplemental service that will help some students realize their right to an adequate education, but it is not a service that actually expands the scope of that right. This may seem overly formalistic, and perhaps it is. Nonetheless, the North Carolina and New Jersey Supreme Courts both relied upon this reasoning.

The North Carolina Supreme Court began by observing that because the General Assembly has the authority to set age limits for school, the court could not order the state to provide school for all four-year-olds. ${ }^{171}$ The court then reasoned that:

when considered in the context of the related issue of prekindergarten programs, the crux of this issue is less about whether school must be offered to four-year-olds than it is about whether the State must help prepare those students who enter the schools to avail themselves of an opportunity to obtain a sound basic education. ${ }^{172}$

Although it ultimately rejected Plaintiffs' claim for preschool, the issue of age eligibility did not preclude judicial review of that claim. The New Jersey Supreme Court relied on similar reasoning to evade the age restriction in the New Jersey Constitution, which extends the right to education only to children five and older. ${ }^{173}$

To be sure, this analytical approach leaves open the possibility that future claims will be made for additional interventions thought necessary to prepare children for kindergarten. It rests, in other words, atop a potentially slippery slope. If preschool is ordered because it is thought necessary to prepare children for school, so too could health care or housing be thought necessary to prepare children for school.

This is a legitimate concern, but not an unanswerable one. To begin, all adequacy claims raise the same slippery-slope issue, either explicitly or implicitly. Whether children succeed in school has a lot to do with what happens outside of school. If the right to an adequate education were taken to its logical conclusion, states could be ordered to provide all sorts of social services that improve the academic performance of children. Yet most courts have proven capable of limiting their focus to school-based services. ${ }^{174}$ Given this history, it should not be difficult for courts to

170. See Hancock, 2004 WL 877984, at *140 n.205 (quoting testimony of Professor Barnett).

171. Hoke, 599 S.E. 2 d at $638-39$.

172. Id. at 639 .

173. Abbott, 710 A.2d at 461-62.

174. See Ryan \& Saunders, supra note 143, at 468-69 (describing additional services ordered by courts). 
distinguish between preschool and social services like health care or housing. The former is obviously school-based and intimately linked to education and the academic process, whereas the latter are several steps removed from that process. This is not to say that courts cannot or should not include social services within adequacy-based remedies, but merely that including preschool does not commit them to doing so.

In sum, in states that have recognized or can be persuaded to recognize a right to an adequate education, there are strong legal arguments for a right to preschool. This should be encouraging news for preschool advocates, given that twelve states have already recognized a right to an adequate education, roughly thirty have yet to decide the issue, and the trend seems clearly in favor of recognizing such a right. ${ }^{175}$

As for the choice between universal access and targeted programs, neither the social science data nor the legal rules are conclusive. The social science data shows that preschool benefits all children, but provides greater benefits to those who are disadvantaged. The right to an adequate education, in turn, can encompass either an undifferentiated approach or one that addresses the differing needs of various students. As a result, strong legal claims can be made for universal preschool and for programs targeted to disadvantaged children. There is nothing unusual or surprising about this, given that a number of inputs - think again of smaller class sizes-could also be part of a general right to adequacy or part of a program designed to meet the special needs of disadvantaged students. All it means, ultimately, is that litigants and courts have a legitimate choice to make in terms of how broad the right and remedy ought to be in a particular case in a particular state.

\section{Preschool and the Right to Equal Educational Opportunity}

Courts and litigants face a similar choice in states that have recognized a right to equal educational opportunity. Like the right to adequacy, the right to equal educational opportunity can support both a universal access claim and a request for a program limited to disadvantaged children. In this context, the latter claim is the stronger one.

Equity decisions typically follow a path familiar to those acquainted with federal equal protection jurisprudence. Courts first determine whether education is a fundamental right or whether a school funding system discriminates on the basis of wealth, a classification which some state courts recognize as suspect. If courts conclude either that education is a fundamental right or that a suspect class is implicated, or both, they apply strict scrutiny and determine whether existing inequalities in funding or

175. See David J. Hoff, States on Ropes in Finance Lawsuits, Educ. WK., Dec. 8, 2004, at 1 (observing that "[a]fter 15 years of litigation over whether states are adequately financing their $\mathrm{K}-12$ schools, the momentum has tipped in favor of those who say they are not"). 
programs are necessary to satisfy a compelling state interest. ${ }^{176}$ If strict scrutiny is not triggered, courts apply the more deferential rational basis test. Usually, the standard of review dictates the outcome, much as it does in federal law, meaning that strict scrutiny leads to a finding of unconstitutionality and rational basis the opposite. ${ }^{177}$ But some state courts have struck down funding systems even while applying a rational basis test, albeit one with more spine than the federal version. ${ }^{178}$

Applying this analytical framework to preschool claims is fairly straightforward, although there are some twists. As discussed, forty states and the District of Columbia provide preschool, but not all disadvantaged children are served. ${ }^{179}$ At the same time, the right to equal educational opportunity has been recognized in nine states. ${ }^{180} \mathrm{~A}$ state required to guarantee equal educational opportunities, and which provides preschool to some but not all children, should have to demonstrate either a compelling state interest or a truly rational basis for failing to serve all children.

States can be expected to argue that a lack of funds justifies offering limited opportunities for preschool. Cost alone is usually not deemed sufficient, by either federal or state courts, to justify denying constitutional rights. ${ }^{181}$ At the same time, however, states surely have an unassailable interest in not wasting public funds. And, indeed, some courts in school funding cases have recognized that states retain authority to ensure that scarce resources are spent wisely. ${ }^{182}$ Unless courts are willing to guarantee absolute horizontal equality, states must be free to refuse funding programs or services that are educationally ineffective or tangential to a school's academic mission. It would be odd, for example, for a court to require a state to ensure that all schools have sufficient resources to offer a course in woodworking because such courses are offered in some schools.

This suggests that, ultimately, whether a state must increase access to preschool will likely (and should) turn on the strength of the social science evidence regarding the benefits of preschool. The reason is simple: the more beneficial preschool is for children, the less a lack of resources

176. See, e.g., Serrano v. Priest, 557 P.2d 929, 951 (Cal. 1977); Horton v. Meskill, 376 A.2d 359, 372 (Conn. 1977); Pendleton Citizens for Comm. Schs. v. Marockie, 507 S.E.2d 673, 680-81 (W.Va. 1998); Campbell County Sch. Dist. v. State, 907 P.2d 1238 (Wyo. 1995).

177. For decisions applying the rational basis test and upholding the challenged funding scheme, see, for example, Shofstall v. Hollins, 515 P.2d 590, 592-93 (Ariz. 1973); Lujan v. Bd. of Educ., 649 P.2d 1005, 1023 (Colo. 1982); Hornbeck v. Somerset County Bd. of Educ., 458 A.2d 758, 789 (Md. 1983).

178. See, e.g., Dupree v. Alma Sch. Dist., 651 S.W.2d 90, 93 (Ark. 1983); Tenn. Small Sch. Sys. v. McWherter, 851 S.W.2d 139 (Tenn. 1993); Brigham v. State, 692 A.2d 384, 397 (Vt. 1997).

179. See supra note 27 and accompanying text.

180. See supra note 142 and accompanying text.

181. See, e.g., Bounds v. Smith, 430 U.S. 817, 824-25 (1977); Bell-Bey v. Williams, 87 F.3d 832, 838 (6th Cir. 1996); Whitney v. Buckner, 734 P.2d 485 (Wash. 1987); Crain v. Bordenkircher, 382 S.E.2d 68 (W. Va. 1989).

182. See, e.g., Rose v. Council for Better Educ., lnc., 790 S.W.2d 186, 193 (Ky. 1989). 
should be considered a compelling or legitimate reason to provide preschool to only a limited group. A lack of resources, for example, presumably would not justify providing fewer teachers in some schools than others.

As discussed, all children can benefit from preschool, although disadvantaged children can benefit more. This leaves courts and advocates with the same basic choice they face in states that recognize a right to an adequate education. On the one hand, there is a decent argument that preschool, once offered, should be universal. Preschool is as beneficial as other programs or services that are explicitly or implicitly required to be available to all. If the right to equal educational opportunity, for example, requires small class sizes for all children, then it should also require equal access to preschool, as the educational benefits of preschool seem equal to or greater than the benefits of small class sizes. To the extent litigants can make this showing, they should have a fairly strong basis for arguing that universal preschool should be included within a court's definition of equal educational opportunity.

That said, an even stronger argument can be made on behalf of disadvantaged children, if only because it is much more difficult to justify distinctions within this group of children than it is to justify distinctions between disadvantaged and relatively affluent children. Equal educational opportunity does not require equal treatment of all children, given that all children are not equally situated. ${ }^{183}$ Children disadvantaged by poverty or otherwise at risk of educational failure certainly can, and perhaps must, be provided additional resources to help level the playing field. Preschool is one of those resources.

States have already limited preschool to those at risk of educational failure, including children disadvantaged by family poverty. Given the strong evidence indicating that these children benefit the most from preschool, states have a plausible argument that scarce resources should be spent where the benefits are the greatest. That is, states would have a decent argument that they have a compelling or legitimate interest in limiting preschool funding to disadvantaged children, where the funds will have the most impact.

But states do not have a comparable justification for serving only some poor children and not others. All of these children can benefit, in the same general way, from preschool. These children are similarly situated in every relevant way, and the potential benefits of preschool to them are significant. As a result, courts should not accept a lack of resources as sufficient justification for providing preschool to some but not all disadvantaged children. Again, courts presumably would not accept a lack of resources as justification for lowering class sizes or providing qualified

183. For discussion of horizontal and vertical definitions of educational equality in the funding context, see Ryan \& Saunders, supra note 143, at 468-69. 
teachers for some poor students but not others. The same should be true for preschool.

For all of these reasons, preschool claims should thus fare well in states that have recognized-or will recognize in the future-a constitutional right to equal educational opportunity. Equity-based claims for preschool could also succeed, it bears mentioning, in states that have tentatively recognized a right to equal educational opportunity but have rejected claims for equal funding. These courts have explicitly rejected a right to equal funding on the ground that a right to equal educational opportunity can be provided without equalized funding. Regardless of its accuracy, this sort of reasoning simply does not apply in the preschool context. $^{184}$ Equality of opportunity cannot be achieved by providing preschool to some and denying it to others, at least where those denied access cannot pay for private alternatives.

When the equity and adequacy-based claims for increased access to preschool are considered together, it becomes clear that there are a number of strong theories upon which to rest these claims. This does not mean that states will roll over in litigation and concede plaintiffs' claims. Consideration of the objections that States will likely raise, however, actually helps highlight the strength of the legal case in favor of preschool.

\section{Objections and Responses}

States can be expected to offer at least three objections. The first is a separation of powers argument, and the point is the simple one that legislatures, not courts, should determine whether preschool is offered and who is eligible to attend. The second and related argument is that the social science evidence does not justify a court-ordered right to preschool. Both objections have already surfaced in preschool cases. ${ }^{185}$ The third objection, which has not yet been made but will not remain offstage for long, is a version of the slippery slope: preschool is analogous to college, and any right to the former would require granting a right to the latter.

\section{Separation of Powers}

The state's separation of powers argument prevailed in Arkansas, where the state supreme court refused to order the state to provide preschool. The court relied heavily on language unique to the Arkansas Constitution, which provides that the legislature "may spend public funds for the education of persons over twenty-one (21) years of age and under six (6) years of age, as may be provided by law, and no other

184. See, e.g., Skeen v. State, 505 N.W.2d 299, 315-18 (Minn. 1993) (concluding that education is a fundamental right but that equal funding is not, and discussing similar holdings of other state courts).

185. Lake View Sch. Dist. No. 25 v. Huckabee, 91 S.W.3d 472, 501-02 (Ark. 2002); Hoke County Bd. of Educ. v. State, 599 S.E.2d 365, 393 (N.C. 2004). 
interpretation shall be given to it." ${ }^{186}$ As the court correctly concluded, this language obviously grants the legislature the authority to determine whether to fund preschool. The court went beyond this language, however, and asserted that whether to provide preschool is a "public-policy issue for the General Assembly to explore and resolve."187 As such, the court determined that it is beyond the power of courts to "mandate pre-school education as an essential component of an adequate education."

The Arkansas court's first argument is difficult to rebut, but it is irrelevant outside of Arkansas. The court's second argument is the opposite-pertinent beyond Arkansas, as it essentially states a general separation of powers argument against court involvement, but not hard to rebut.

To begin with the obvious, constitutional language requires interpretation and implementation, including language in state constitutions that creates an affirmative right to education. The overwhelming majority of courts entertaining school funding suits have reached this conclusion. Though not all cases have been successful, very few have been rejected outright on separation of powers grounds. ${ }^{189}$ If courts are willing, as they should be, to dctermine whether state constitutions create a right to equal or adequate educational opportunities, they must be committed to defining the content of those opportunities. This point cannot be emphasized enough: given that no state constitution defines the elements of an adequate or equal educational opportunity, courts must, at some point, give content to these rights.

Preschool claims simply ask courts to carry out this task. Courts may determine that, on the merits, preschool should not be included as part of a student's right to equal or adequate educational opportunities. But it would be unjustified for a court to determine that the decision about this particular input (preschool) must be left to the legislature, while identifying the other inputs that must be included within any definition of the right to equal or adequate educational opportunities. To return to Arkansas, it is hard to understand how the court could decide, on the one hand, that students have a right to an adequate education and adequate funding, while at the same time declaring that it would violate separation of powers principles even to address whether that right should include access to preschool. ${ }^{190} \mathrm{By}$

186. ARK. Const. art. 14, $\S 1$ (emphasis added). The Arkansas Supreme Court determined that "[t]his language could not be clearer. The General Assembly, and it alone, provides what earlychildhood-education programs shall be implemented." Lake View Sch. Dist. No. 25 v. Huckabee, No. 01-836, 2004 WL 1406270 (Ark. June 18, 2004).

187. Lake View, 91 S.W.3d at 501-02.

188. Id.

189. See Verstegen, supra note 135 , at 508.

190. Indeed, the court emphatically declared, in an earlier opinion, that the question of whether students in Arkansas were receiving a constitutionally adequate education must be determined by the judiciary. Lake View, 91 S.W.3d at 484. 
deciding the funding question, the court confirmed that the issue of adequacy is justiciable. If courts conclude they are authorized and competent to assess the inputs and outputs necessary to give life to the right to an adequate education, they are necessarily authorized and competent to decide the preschool question.

As a practical matter, moreover, it is important to recognize that courts would not be asking legislatures to adopt completely new programs. In a very real sense, state legislatures in the forty states that offer preschool programs have already committed to providing preschool and to including it as part of public education. A court that ordered a state to increase access to preschool would not be forcing the state to offer an entirely new education program, which the state might believe is ineffective or inefficient. Instead, the court would simply be determining that principles of equity or adequacy require the state to expand access to a pre-existing, legislatively created program.

The fact that legislatures already offer some students preschool also helps answer a more specific separation of powers argument, which arose in the North Carolina case, relating to age-eligibility for public education. States may contend, as did North Carolina, that they have unfettered authority to determine who is eligible for public education. ${ }^{191}$ One possible response, already discussed, is that preschool is not the beginning of public education, but rather a special program designed to help disadvantaged children prepare for the start of their "real" education. ${ }^{192}$ Another less formalistic response focuses on the fact that states have already determined that some four-year olds, and in some instances three-year olds, are eligible for preschool. It would be odd if, having made this determination, states could prevent courts from determining whether access to preschool should be expanded on the ground that only the legislature can determine who is age-eligible for public education.

The Massachusetts trial court's decision in Hancock v. Driscoll illustrates the point. The court noted that the state constitution requires that education be provided at the "public school level," but does not identify the boundaries of that "level." 193 By statute, the state board of education establishes mandatory ages of school attendance. In each of the plaintiff districts, however, some children attended publicly funded preschool programs. Curriculum frameworks adopted for all public schools by the State Board, moreover, included a preschool component. Because of these facts, the court concluded "that the Commonwealth does in fact include preschool programs as part of the education prescribed at 'the public

191. Hoke County Bd. of Educ. v. State, 599 S.E.2d 365, 391-92 (N.C. 2004).

192. Id.

193. Hancock v. Driscoll, No. 02-2978, 2004 WL 877984, at*1-2 (Mass. Super. Apr. 26, 2004) (citing McDuffy v. Sec. of Exec. Office of Educ., 415 Mass. 545 (Mass. 1993)). 
school level.""194 The same basic argument can be made against states that, by their own actions, have created public preschool programs and made preschool a part of the public school system. In short, these states should not be able to use the issue of age-eligibility to shield themselves from court review.

\section{Social Science Evidence and Deference}

The second, related objection, a version of which also arose in the North Carolina case, is that the evidence regarding the benefits of preschool is not yet strong enough to justify a court mandate requiring it. ${ }^{195}$ This argument is related to the first objection because the more debatable the benefits of preschool, the more this seems like an issue for the legislature to resolve. This objection is easily answered, at least in those states whose courts have already overturned school funding systems. As discussed previously, the social science evidence regarding the benefits of preschool is quite strong. The social science evidence regarding the general relationship between funding and achievement, by contrast, is quite contested, as is some of the data regarding specific inputs, such as small class sizes. ${ }^{196}$ If courts do not find the lack of undisputed evidence an insuperable obstacle in traditional school funding suits, they should not be deterred by the generally stronger evidence regarding the benefits of preschool.

There is a subtler version of this argument, which carried the day in North Carolina, and echoes of which can be heard in the Massachusetts Supreme Court decision. The North Carolina Supreme Court agreed with the trial court that the state must provide at-risk children additional services designed to meet their special needs. The court also agreed that this obligation extended to children who had not yet entered kindergarten, a group the court referred to as "prospective enrollees." But the court refused to order preschool as the service the state must provide. The court concluded that ordering preschool would be premature because the state was already moving in that direction, and because plaintiffs failed to prove that preschool was necessarily the most effective program to prepare four-year-olds for school. ${ }^{197}$

In essence, the court allowed the state the first opportunity to determine how best to prepare disadvantaged children for schooI. This is a completely defensible position. It is also one that preschool advocates should welcome, albeit as a second-best resolution, because it most likely will lead to increased access to preschool. The reason is the lack of viable

194. Id.

195. Hoke, 599 S.E.2d at 394.

196. See supra notes 156 through 158 and accompanying text.

197. See Hoke, 599 S.E.2d at 394; see also Hancock, 2005 WL 332016, at *3, *17 (finding that programs other than preschool "might be equally effective to address the needs of at risk students"). 
alternatives. Notwithstanding the North Carolina Supreme Court's agnosticism, there is no evidence that any other program, for the same or a smaller investment, would be as effective as preschool in preparing students for kindergarten and first grade. States should either reach this conclusion on their own, or they should be told as much by courts after a reasonable period of time. Indeed, this is basically the path followed in New Jersey, where the court eventually ordered preschool to be provided after giving the state time to develop supplemental programs for disadvantaged children, which the state failed to do. ${ }^{198}$

\section{If Preschool, Then College?}

The third objection, which has not yet arisen but can be anticipated, is that any court decision to increase access to preschool would also require increasing access to public colleges or universities. Somewhat surprisingly, the issue of whether students have a fundamental right to higher cducation has arisen in only one case, Gurfinkel v. Los Angeles Community College District. ${ }^{199}$ Previously, in Serrano v. Priest, the California Supreme Court had declared education to be a fundamental right. ${ }^{200}$ The plaintiff in Gurfinkel sought to extend that right to higher education, arguing that residency requirements for community colleges infringed her fundamental right to education. ${ }^{201}$

The California Court of Appeals rejected her claim, refusing to extend Serrano and ruling that access to higher education is not a fundamental right. ${ }^{202}$ In rejecting Plaintiff's claim, the court relied on the fact that she had introduced no evidence documenting the benefits of higher education. The Serrano court declared education a fundamental right in part because of the benefits bestowed by education. ${ }^{203}$ By failing to link higher education to similar benefits, Gurfinkel failed to make a convincing case for extending the reach of Serrano to cover higher education. ${ }^{204}$

Despite this outcome, it is not difficult to imagine a better-argued case, in which plaintiffs demonstrate the importance of a college education to ensuring economic success. This could form the basis for an adequacy argument and provide a rationale for extending the right to an adequate education upward to higher education, just as demonstrating the benefits of preschool would form the basis for extending a right of adequacy downward. One could also imagine an equity-based argument where plaintiffs

198. Abbott v. Burke, 710 A.2d 450, 461-62 (N.J. 1998).

199. 175 Cal. Rptr. 201 (Cal. Ct. App. 1981).

200. Serrano v. Priest, 557 P.2d 929, 951 (Cal. 1977).

201. 175 Cal. Rptr. at 203.

202. Id.

203. Serrano, 557 P.2d at 951.

204. Gurfinkel, $175 \mathrm{Cal}$. Rptr. at 203. 
contend that states should provide similar scholarship funds to all students who are similarly situated.

There is no denying some parallels between preschool and higher education claims. Indeed, those interested in expanding access to community colleges and public universities may wish to cmphasize the similarities rather than the differcnces. Nonetheless, there are strong reasons why recognizing a right to preschool need not commit courts to recognizing a right to higher education.

To begin, the practical effects of requiring students to pay a fee to attend school are diffcrent in the two contexts, because students entering higher education have access to capital and the ability to borrow against future earnings. Perhaps it goes without saying that there is no comparable market for student loans for preschoolers. If preschoolers must pay to attend, therefore, those from poor families will be completely denied access; the same is not generally true in the context of higher education, although paying for collegc is certainly still very difficult for some students and their families. This difference has doctrinal significance. Even if the right to adequate or equal cducational opportunities encompassed higher education, requiring tuition would not necessarily violate that right because it would not cffectively deny access to higher education. In this regard, it is telling that the Gurfinkel plaintiff argued that she should be able to pay in-state rather than non-state tuition, not that access should be free.

Putting aside issues of payment, preschool is also more closely connected to primary and sccondary education, which are unquestionably protected by all state constitutions. Preschool helps children prepare for K-12 education, and its benefits can impact their performance during thesc years. Higher education, by contrast, is what a $\mathrm{K}-\mathrm{I} 2$ education should prepare students to do; that is, being able to enter higher education is one of the goals of primary and secondary education. It is therefore easier to justify including access to preschool as a part of a student's well-established right to a $\mathrm{K}-12$ education than it is to justify including access to higher education. Recall the reasoning of the four courts that were willing to recognize a right of access to preschool for disadvantaged children. They concluded that disadvantaged children need preschool in order to prepare them for primary education and therefore realize their right to an adequate education. ${ }^{205}$ This rationale simply does not apply to higher education.

Last, states have not created programs for higher education that are comparable to the public preschool programs already available in forty states and the District of Columbia. States may provide financial aid to college students, and full scholarships to other students. But no state, as far as I can tell, offers free access to higher education to a certain percentage of poor students. This difference, too, has doctrinal significance. An

205. See supra notes 160 through 168 and accompanying text. 
equity-based claim for greater access to preschool has merit and force because existing programs extend to some but not all disadvantaged children, who are for this purpose similarly situated. Similarly blatant discrimination does not appear to infect existing financial aid and scholarship programs. These programs do indeed distinguish among students, but the students are not similarly situated in terms of financial need or merit.

\section{III \\ The EfFicacy of Court Decisions}

The legal claim for increased access to preschool is strong, and the objections that could be raised to such a claim are answerable. This bodes well for success in court, but that is only the first step. Even assuming that courts side with plaintiffs and order increased access, how effective will such rulings be in practice?

Any answer will necessarily be speculative, but it is possible to make an informed estimate. Political scientists and legal historians have studied impact litigation in an effort to determine whether and when court decisions are effective at creating social change. This scholarship, typified by Gerald Rosenberg's The Hollow Hope ${ }^{206}$ and Michael Klarman's recent book, From Jim Crow to Civil Rights: The Supreme Court and Racial Equality, ${ }^{207}$ is generally quite skeptical of the ability or inclination of courts to prompt social change. But scholars working in this area, including Rosenberg and Klarman, do not deny that courts can be effective under the right circumstances.

Instead, after examining the impact of a host of litigation campaigns, these scholars have identified a set of factors that make it more or less likely that litigation will affect social change. These factors include: the intensity of opposition; whether legislators and administrators view court orders as helpful political cover for leveraging more resources for programs they already favor; whether market mechanisms will help implement the newly created right; the ease with which rulings can be evaded; and the determination, resources, and strategies of those seeking to enforce the right. ${ }^{208}$ By examining how those factors operate in the political context of preschool, one can reasonably assess the likely impact of a favorable court ruling.

Notice that most of these factors relate to the underlying political popularity of the issue or cause. This suggests, as would intuition, that the

206. ROSENBERG, supra note 25.

207. Michael J. Klarman, From Jim Crow to Civil Rights: The Supreme Court and Racial EQuality (2004).

208. See, e.g., id. at 454-68; Rosenderg, supra note 25, at 9-36; STUart A. SCHeINGold, THE Politics of Rights: Lawyers, Public Policy, and Political Change (2d ed. 2004); Paris, supra note 23 , at $633-37$. 
more popular a cause, the more likely that a court ruling promoting that cause will be implemented by legislatures and administrators. This does not mean that court rulings are effective only when unnecessary, as there are a number of reasons-including sheer inertia-why relatively popular programs do not get enacted. ${ }^{209}$ What it does mean, however, is that courts are likely to be most effective when pushing against a door that is already ajar. $^{210}$

It is important to emphasize, finally, that any judgment about effectiveness must be a relative one. The relevant question is not whether a court ruling is "effective" in some abstract sense, but whether the end result is better than the probable alternatives. In this context, court orders should be considered effective if they lead to more children enrolling in quality preschool programs than would enroll in the absence of a court order. This is a difficult analysis to conduct, of course, given that it requires comparing two speculative scenarios. But it is nonetheless a helpful way to maintain the proper perspective.

\section{A. Political Support and Opposition}

Preschool is fairly popular across the political spectrum. Although most polls should be viewed with healthy skepticism, polling nonetheless reveals consistent support for expanding access. One recent national poll, for example, indicated that nearly $90 \%$ of voters support state funding of quality preschool programs for all three- and four-year-olds. ${ }^{211}$

Looking beyond polls, Business Week recently touted universal access to publicly funded preschool as one of its " 25 Ideas for Changing the World." 212 The Committee for Economic Development, an organization composed of some 250 business leaders and educators, recently issued a report advocating universal access to preschool. ${ }^{213}$ So, too, did the Business Round Table and Corporate Voices for Working Families, two associations of business leaders from major corporations. ${ }^{214}$ Fight Crime: Invest in Kids, a bipartisan anti-crime group that includes police chiefs and district

209. Cf. Richard A. Posner, Appeal and Consent, New Republic, Aug. 16, 1999, at 36 (acknowledging imperfections in the political process).

210. Cf. KLARMAN, supra note 207, at 463 (concluding from his comprehensive review of Court decisions in the area of race that "[l]itigation is unlikely to help those most desperately in need").

211. One poll showed that $87 \%$ of adults surveyed "strongly support" or "somewhat support" providing funding and financial support for preschool programs so that all parents who want to can afford to enroll their children. National Institute for Early Education Research, National Poll Conducted by Peter D. Hart Research Associates/Market Strategies: November-December 2001, http://nieer.org/resources/research/poll802/nationalsummary.pdf.

212. Alexandra Starr, 25 Ideas for a Changing World, Bus. WK. OnLine, at I (Aug. 26, 2002), http://www.businessweek.com/magazinc/content/02_34/b3796661.htm.

213. CED, PresChool For All, supra note 3, at 1 ("The Committee for Economic Development (CED) calls on the federal and state governments to undertake a new national compact to make early education available to all children age 3 and over.").

214. Business RoundTABLE, supra note 90. 
attorneys, has made early education programs a major focus of its advocacy efforts. ${ }^{215}$ The United Way supports expanding access to preschool, ${ }^{216}$ as does the American Federation of Teachers. ${ }^{217}$ Even the Federal Reserve Bank of Minneapolis has urged states to invest in early education programs, arguing that it is a wise economic development strategy. ${ }^{218}$

Part of the attraction of preschool, for both liberals and conservatives, is that it seems to be a smart, efficient, and proven way to get young kids on the right track and thereby avoid larger problems down the line. It is intuitive, regardless of political ideology, that avoiding problems is usually easier and less costly than fixing them. The views of the Republican trial judge in North Carolina, who raised the issue of preschool sua sponte, are instructive. As he told an interviewer:

The pre-k idea in my mind came about before I ever heard about this case. I would see every day as a judge all of these kids - most of them black and most of them poor-all selling drugs and all going to jail. And for all of them, highest grade completed in school? Eighth. You see this constant barrage as a judge. I made up my mind that something is not right and you've got to do something with them early. ${ }^{219}$

In contrast to the widespread and diverse support for increasing access to preschool, opposition to the idea seems weak. ${ }^{220}$ Perhaps opposition groups may emerge over time, but there is little on the horizon at this point, despite the considerable legislative activity on this issue.

There would undoubtedly be a good deal of opposition if preschool were made mandatory, but there is no reason why courts would have to recognize a right of access and then require attendance. Kindergarten provides a useful comparison: students in most states have a right to attend, but attendance is compulsory in only thirteen states. ${ }^{221}$ Indeed, most constitutional rights, whether state or federal, need not be exercised, and it is certainly not the case that all potential beneficiaries of a claimed right must exercise it in order for the right to be recognized. That most women will

215. See, e.g., Keiko Morris, Studies Link Pre-K Cuts, Crime, Newsday, Apr. 28, 2003 (noting that Fight Crime: Invest in Kids issued a report estimating that cuts in preschool programs will increase crime and lead to an overall loss of millions of dollars).

216. It does so through its "Success by Six" program. For a description, see http://www.uwbg.org/initiatives/successbysix.

217. Am. Fed'n of Tchrs., At the Starting Line: Early Childhood Education Programs in The so States 6 (2002) [hereinafter Am. Fed'N OF TChrs., At the Starting Line] (recommending that preschool be made available "to all 3- and 4-year olds, beginning with disadvantaged children").

218. Rolnick \& Grunewald, supra note 102.

219. Almeida, supra note 169, at 535 n.74 (quoting Judge Howard E. Manning, Jr.).

220. The Cato Institute, a libertarian interest group, has expressed some opposition, but it is doubtful that this single group wields much influence. See Olsen, supra note 67.

221. See Michelle Galley, State Politics on Kindergarten Are All Over the Map, in QualitY CounTs 2002, Educ. WK., Jan. 10, 2002, at 45. 
not exercise their right to an abortion, for example, did not prevent recognition of the right.

If attendance is not compulsory, expanding access to preschool should not generate the sort of pitched social battles that comprise the so-called culture wars, in the way that abortion or gay rights cases have. Some socially conservative groups might complain that encouraging preschool will upset traditional family structures, where women stay at home with their children. They will be bucking a strong demographic trend, of course, and arguing against what over two-thirds of all mothers of young children already do, namely work out side of the home. ${ }^{222}$ In part because of this, it seems unlikely that these groups will mount the same sort of opposition to preschool that thcy have offered on the more socially charged issues of abortion and gay rights.

\section{B. Providing Political Cover}

That said, expanding access to preschool will require increased funding or cuts in existing programs, and this will spark some opposition. ${ }^{223}$ It is difficult to predict the breadth or depth of this opposition, although it again seems unlikely to match the intensity of opposition to gay marriage, abortion, or, in the past, school desegregation. Nonetheless, fear of political repercussions presumably explains, at least in part, why most legislatures have not taken the steps to fully fund public preschool programs despite the apparent popularity of increasing access to preschool.

Under these circumstances, a court decision may be quite helpful in promoting social change insofar as it can provide political cover. Where legislators would like to increase access to preschool, but are afraid to do so, a court decision ordering them to increase access helps politicians shoulder the burden. Legislators can point to the court order and explain that they have no choice but to comply with a constitutional requirement. School finance decisions, which also require increased expenditures, have played this role in a number of states, ${ }^{224}$ and there is good reason to expect favorable decisions regarding preschool to play the same role.

222. CED, Preschool For All, supra note 3, at 7.

223. There are examples from the school finance realm where calls to raise taxes have generated fierce and effective opposition. Governor Jim Florio, for example, became the first governor of New Jersey not elected to a second term in office largely because of his proposal to raise taxes in order to increase education spending. Florio proposed his legislation before the New Jersey Supreme Court's decision and thus lost the ability to take cover under the court order. See Douglas S. ReEd, ON Equal Terms: The Constitutional Politics of Educational Opportunity 86 (2001); Denise C. Morgan, The New School Finance Litigation: Acknowledging That Race Discrimination in Public Education Is More Than Just a Tort, 96 Nw. U. L. REv. 99, 142 \& n.214 (2001).

224. See Paul W. Kahn, State Constitutionalism and the Problems of Fairness, 30 VAL. U. L. Rev. 459,468 (1996) (suggesting that "successful litigation has more often been the product, not the cause, of a political consensus that the schools need fundamental change"); Paris, supra note 23, at 633-34 (discussing Kentucky); James E. Ryan, The Influence of Race in School Finance Reform, 98 MicH. L. 
Indeed, they already have, as reactions to the trial court rulings in Massachusetts and North Carolina illustrate. Prior to the trial court's ruling, legislators in Massachusetts had already begun debating whether to offer universal access to preschool. The Democratic House Speaker, months before the decision, expressed support for a ten-year plan to implement universal access to preschool. ${ }^{225}$ Three days after the decision, the Speaker went further and proposed an amendment to the state budget that would begin to phase in a universal preschool program in $2005 .{ }^{226}$ The Speaker remarked that this program "would prove us responsive" to the court ruling, clearly tying his proposal to the recent court order. ${ }^{227}$ It cannot escape notice that he and others already supported expanding access to preschool, and that the trial court's ruling at the time was on appeal and could be overturned-as it eventually was. The court order thus assisted legislators who were already inclined to expand access to preschool.

The political reaction in North Carolina was quite similar. Before the trial court's ruling, which called for increased access to preschool for atrisk children, the Governor had created the "More at Four" program. ${ }^{228}$ The program sought to expand access to presehool for four-year-olds in North Carolina. In the summer of 2002 , the Governor relied on the recent trial court ruling to coax more funds from the legislature for the preschool program, telling legislators in a letter that the "court order is not going away" and that the lawsuit had reached a "crisis point."229 The appeal resonated. As one member of the General Assembly remarked, "[o]ne of the justifications the legislature has used to fund More at Four during a time of severe budgetary constraints is that it is court-ordered." 230

\section{Market Support}

Those with a financial interest in preschools would also support court decisions requiring increased access. Most state-sponsored preschool programs, as mentioned, already include both public and private providers. If courts ordered states to expand access to preschool, there is every reason to expect that private providers would continue to be eligible to participate in state programs. These providers and their trade organizations can be

REv. 432, 468-69 (1999) [hereinafer Ryan, Influence of Racel (discussing Massachusetts and Washington).

225. Brenda J. Buote, Putting the Focus on Preschoolers Report Makes State Recommendations, Boston Globe, March 11, 2004, at 1.

226. Shaun Sutner, Finneran to Present Plan for Free Preschool, Worcester Telegram \& GAzETTE, Apr. 29, 2004, at A2.

227. Id.

228. Almeida, supra note 169 , at 565

229. Amy Gardner \& Todd Silberman, Easley Demands Quick Action on Lottery, RaLeIGH News \& ObSeRver, July 23,2002 , at B1.

230. Almeida, supra note 169 , at 566 (quoting state representative and education committee member Deborah Ross). 
expected to take a strong interest in legislative responses to court decisions. ${ }^{231}$ So, too, will teachers' unions, which have already come out in favor of universal access to preschool, without insisting that it be provided in public schools. $^{232}$

The reaction to the trial court's decision in Massachusetts is again instructive. Those with a financial stake lost little time in expressing support for the Speaker's plan to create universal access to preschool. The executive director of the Massachusetts Association of Day Care Agencieswhich has counterparts in other states-called the Speaker's plan "an important first step" toward making "early education and care ... a priority in Massachusetts." 233 Not surprisingly, he also supported and emphasized the Speaker's plan to elevate the pay of preschool teachers. ${ }^{234}$ The legislative story is far from over in Massachusetts, in part because the trial court's decision was reversed on appeal. The initial reaction is nonetheless instructive insofar as it highlights the sort of political and market-based dynamic that could transform a court ruling into effective legislation.

\section{Ease of Evasion and Strength of Advocates}

Political and market support for expanding access to preschool is crucial because court rulings will be fairly easy to evade. To be sure, ease of evasion will depend to a certain extent on the nature of the ruling. The more expansive the right, the harder it will be to evade. A ruling that requires universal access to preschool for all four-year-olds, for example, will be harder to evade than one that requires access only for at-risk fouryear-olds. The latter provides more opportunity for manipulation insofar as legislatures presumably will have some room to define the "at-risk" category. But regardless of the nature of the ruling, legislatures will have discretion as to how to implement the right. If they are recalcitrant, one should expect begrudging compliance at best, which might mean that formal access is provided, but the programs are under-funded and weak.

Should legislatures prove sluggish or recalcitrant, effective implementation will require attentive and determined advocates, and equally attentive and determined courts. ${ }^{235}$ If the history of school finance litigation is any indication, some states will fare better on this score than others. In that

231. For example, the National Child Care Association, which is a trade association representing more than 100,000 licensed child care centers, has called for universal access to preschool. National Child Care Association, Building Universal Preschool in Partnership with the Private Early Education and Care System (Aug. 2001) (unpublished paper, on file with author).

232. See Am. FeD'N of Tchrs., At the Starting Line, supra note 217.

233. Id.

234. Id.

235. See KLARMAN, supra note 207 , at $458-60$ (identifying certain factors as important determinants to effectiveness of litigation); Charles R. EpP, The Rights Revolution: Lawyers, Activists, and Supreme Courts in Comparative Perspective 23 (1998) (same). 
context, some litigants and state courts, after declaring finance systems unconstitutional, have remained inactive in the face of legislative recalcitrance. ${ }^{236}$ Other litigants and state courts have pursucd legislatures doggedly, including those in New Jersey, where the Supreme Court has issued more than fifteen decisions throughout the thirty years of school finance litigation in that state. ${ }^{237}$ In the context of preschool, the fact that so many interest groups-including business groups and teachers' unions, which presumably have access to substantial resources-support expanding access to preschool makes it more likely that litigation efforts will be well funded. Although money does not guarantee effective litigation, it certainly helps.

\section{E. Timing, Effective Losses, and Political Competition}

Conditions seem favorable for producing relatively effective court decisions. It is impossible to know, of course, what would happen in the absence of litigation. Many state legislatures have alrcady created preschool programs; some have made access universal or nearly so, and others are moving in that direction. At least in some states, it is possible that allowing legislatures time to expand access incrementally may be more beneficial than litigating immediately. Programs created by legislatures rather than those commanded by courts might be better crafted and presumably would enjoy more political support.

Unless there is a significant risk of backlash, however, there is reason to expect that litigation will further rather than hinder the cause of expanding access to quality preschool programs. The risk of backlash, for reasons discussed above, seems slight. Recognizing a right to preschool, unlike recognizing a right to abortion, seems unlikely to impede the legislative progress by fomenting opposition. ${ }^{238}$ Under these circumstances, litigation can be expected to aid the political process, not cause it to go haywire. Additionally, litigation might still be worthwhile even in states that presently seem committed to providing preschool. Creating a constitutional right of access would protect preschool programs from diminution or elimination in times of budgetary crunches, transforming them from discretionary grants into entitlements.

Even where litigation is successful, there will remain a host of complicated questions to resolve. A right to preschool, even if implemented, does not address the broader issue of childcare for working parents. These

236. Cf. Ryan, Schools, Race, and Money, supra note 140, at 267-68 \& n.77 (discussing legislative reactions to school finance decisions).

237. See, e.g., Greif, Politics, Practicalities, and Priorities, supra note 157, at 618-52 (discussing New Jersey litigation).

238. See Ruth Bader Ginsburg, Some Thoughts on Autonomy and Equality in Relation to Roe $v$. Wade, 63 N.C. L. REv. 375, 382, 385 (1985); Ruth Bader Ginsburg, Speaking in a Judicial Voice, 67 N.Y.U. L. REV. 1185, 1205-08 (1992). 
parents typically need more care for their children than most preschool programs currently provide. ${ }^{239}$ How to combine Head Start funds and standards with state funds and standards, and whether federal money would continue to flow as state programs expand, raise equally complex questions. If preschool is provided only to disadvantaged children, there is also a large and important question as to whether those children will be able to attend economically diverse preschools or will be limited to schools open only to poor children. Finally, there is a political risk that any program limited to the poor will end up being a poor program and one with insufficient public support to remain viable. ${ }^{240}$

In light of the inevitable complications that will arise, not to mention the unforeseen and unintended consequences, it would be wise to temper one's expectations regarding what courts alone can accomplish. To translate a court victory into effective legislation will require continued advocacy beyond the courtroom, and it may well require ongoing collaboration between courts and legislatures. The recognition of a right of access, in other words, is only one element of a larger political effort that will be necessary to expand access to high-quality preschool. ${ }^{241}$

At the same time, it bears mentioning that even unsuccessful litigation may indirectly spur legislative action. The Arkansas Legislature, for example, increased spending for preschool even after the supreme court concluded that the state constitution did not guarantee access. ${ }^{242}$ As past studies have demonstrated, litigation raises the salience of an issue, regardless of its ultimate outcome, and it tends to force legislators to take a position. ${ }^{243}$ Similarly, it can help foster and inspire a political movement by drawing attention to the issue. The preschool cause is a fairly compelling one, which can draw support not only from social science evidence regarding the benefits of preschool, but also from appeals to basic notions of equality. It may well be that legislators, when pressed, would have a hard time explaining why there is only enough money to offer preschool to a small percentage of those who cannot afford to attend.

In addition, it is important to recognize that litigation need not succeed in every state in order to promote the growth of preschool programs. The dynamics of interstate competition could very well create pressure on some states to match their neighbors' commitment to preschool education.

239. CED, PRESCHOOL FOR All, supra note 3, at 12.

240. Wilbur J. Cohen \& Milton Friedman, Social Security: Universal or Selective? 55 (1972).

241. Cf. SCHEINGOLD, supra note 208 , at 148 (arguing that "rights are most sensibly thought of as agents of political mobilization rather than as ends in themselves").

242. See Lake View Sch. Dist. No. 25 v. Huckabee, No. 01-836, 2004 WL 1406270 (Ark. June 18, 2004). Whether litigation prompted the legislative action is hard to determine, but the timing of it certainly suggests that litigation may have motivated at least some legislators to act.

243. See, e.g., Klarman, supra note 207, at 463-64; Michael McCanN, Rights at Work: Pay Equity Reform and the Politics of Legal Mobilization (1994). 
This same dynamic has been documented in the school funding arena. ${ }^{244}$ If preschool becomes an established component of education in enough states throughout the country, legislatures and officials may come to see it as a way to compete for businesses and residents. State court rulings, in short, could spur a race to the top. ${ }^{245}$

\section{CONCLUSION}

As I mentioned at the outset, it is popular in the legal academy and among political scientists to question the efficacy of litigation as an agent of social change. There are good reasons to raise these questions. Studies of past legal campaigns demonstrate that courts, including the Supreme Court, have limited power, and that even successful judicial decisions do not neatly translate into effective and productive policies. ${ }^{246}$ When they initially appeared, these studies served as important counterweights to casual claims of judicial efficacy, articulated by both proponents and opponents of "judicial activism." 247 At this point in time, however, it is possible that they have helped push the pendulum too far toward the direction of what might be called judicial defeatism. ${ }^{248}$

Hope should not always triumph over experience. At the same time, however, past experiences should not blind one to future opportunities. Though courts have not always been successful in promoting social change, this does not mean that their involvement in this context is destined to be futile or counterproductive. To the contrary, there are reasons to be sanguine about the ability of courts to play a productive role in an effort to expand access to preschool. No court ruling on its own will secure access to high-quality preschools for all who need it. As much, if not more,

244. John Shannon, Federalism's "Invisible Regulator"-Interjurisdictional Competition, in Competition Among States and Local Governments: EfFiciency and Equity in American Federalism 119-21 (Daphne A. Kenyon \& John Kincaid eds., 1991).

245. There is a risk that a constitutional right available only to poor children could have the opposite effect. If programs are limited to poor children, they may be viewed as a form of welfare and wealth redistribution. The literature on interjurisdictional competition contains competing views about the benefits and dangers of such competition, but there is consensus on the point that states have strong incentives not to redistribute wealth, given the relative ease of exit. See Ryan, Perverse Incentives, supra note 26 , at $949-51$ (reviewing the literature). There is good reason to expect, however, that even if courts limit a right of access to poor children, legislatures will face-and eventually accede topressure to grant wider access. See, e.g., Ryan, Influence of Race, supra note 224, at 459-60 (describing how the New Jersey legislature increased funding for all schools in response to court orders requiring increased funding for certain districts).

246. See supra note 21 .

247. See Malcolm M. Feeley, Hollow Hopes, Flypaper, and Metaphors, 17 Law \& Soc. InQUIRY $745,747-48$ (1992) (examining Rosenberg's work on the limited ability of courts to effectuate social change).

248. See David J. Garrow, Happy Birthday, Brown v. Board of Education? Brown's Fiffieth Anniversary and the New Critics of Supreme Court Muscularity, 90 VA. L. REv. 693, 722-28 (2004) (describing and sharply criticizing this trend). 
work will need to be done after any court decision if a right of access is to be translated into an effective policy.

The fact that courts cannot control the fate of their decisions is not a reason for them to remain idle. It is a reason, however, to temper one's views about the role of courts in producing social change. For those with inflated expectations about what courts can accomplish, their hope about the power of courts to produce social and political change will often be hollow. ${ }^{249}$ Those who begin with a more modest conception of a court's ability to produce social change, by contrast, are less likely to be disappointed.

State legislatures and executive officials have already started down the path of providing access to preschool. Court decisions recognizing a right to preschool should move them further along that path. The ultimate destination will not be dictated by any court, as legislatures and officials will determine which of many forks in the road to take. But there is reason to be optimistic that the trip will be a productive one, leading more children to quality preschool programs, which would benefit them and the rest of us.

249. Malcom Fceley makes this point in his revicw of Rosenberg's work. Feeley, supra note 247, at $749-52$. 
